\title{
Evaluation of the new DWD ozone and temperature lidar during the Hohenpeißenberg Ozone Profiling Study (HOPS) and comparison of results with previous NDACC campaigns
}

\author{
Robin Wing ${ }^{1}$, Sophie Godin-Beekmann ${ }^{1}$, Wolfgang Steinbrecht ${ }^{2}$, Thomas J. McGee ${ }^{3}$, John T. Sullivan ${ }^{3}$, \\ Sergey Khaykin ${ }^{1}$, Grant Sumnicht ${ }^{3}$, and Laurence Twigg ${ }^{3}$ \\ ${ }^{1}$ LATMOS/IPSL, OVSQ, Sorbonne Universités, CNRS, Paris, France \\ ${ }^{2}$ Deutscher Wetterdienst, Met. Obs. Hohenpeißenberg, Hohenpeißenberg, Germany \\ ${ }^{3}$ NASA Goddard Space Flight Center, Greenbelt, MD, USA
}

Correspondence: Robin Wing (robin.wing@latmos.ipsl.fr)

Received: 30 September 2020 - Discussion started: 10 November 2020

Revised: 30 March 2021 - Accepted: 12 April 2021 - Published: 25 May 2021

\begin{abstract}
A newly upgraded German Weather Service (DWD) ozone and temperature lidar $(\mathrm{HOH})$ located at the Hohenpeißenberg Meteorological Observatory $\left(47.8^{\circ} \mathrm{N}\right.$, $11.0^{\circ} \mathrm{E}$ ) has been evaluated through comparison with the travelling standard lidar operated by NASA's Goddard Space Flight Center (NASA GSFC Stratospheric Ozone (STROZ) lidar), satellite overpasses from the Microwave Limb Sounder (MLS), the Sounding of the Atmosphere using Broadband Emission Radiometry (SABER), the Ozone Mapping and Profiler Suite (OMPS), meteorological radiosondes launched from Munich ( $65 \mathrm{~km}$ northeast), and locally launched ozonesondes. The "blind" evaluation was conducted under the framework of the Network for the Detection of Atmospheric Composition Change (NDACC) using 10 clear nights of measurements in 2018 and 2019. The campaign, referred to as the Hohenpeißenberg Ozone Profiling Study (HOPS), was conducted within the larger context of NDACC validation activities for European lidar stations.

There was good agreement between all ozone lidar measurements in the range of 15 to $41 \mathrm{~km}$ with relative differences between co-located ozone profiles of less than $\pm 10 \%$. Differences in the measured ozone number densities between the lidars and the locally launched ozone sondes were also generally less than $5 \%$ below $30 \mathrm{~km}$. The satellite ozone profiles demonstrated some differences with respect to the ground-based lidars which are due to sampling differences and geophysical variation. Both the original and new DWD
\end{abstract}

lidars continue to meet the NDACC standard for lidar ozone profiles by exceeding $3 \%$ accuracy between 16.5 and $43 \mathrm{~km}$. Temperature differences for all instruments were less than $\pm 5 \mathrm{~K}$ below $60 \mathrm{~km}$, with larger differences present in the lidar-satellite comparisons above this region. Temperature differences between the DWD lidars met the NDACC accuracy requirements of $\pm 1 \mathrm{~K}$ between 17 and $78 \mathrm{~km}$.

A unique cross-comparison between the HOPS campaign and a similar, recent campaign at Observatoire de Haute-Provence (Lidar Validation NDACC Experiment; LAVANDE) allowed for an investigation into potential biases in the NASA-STROZ reference lidar. The reference lidar may slightly underestimate ozone number densities above $43 \mathrm{~km}$ with respect to the French and German NDACC lidars. Below $20 \mathrm{~km}$, the reference lidar temperatures profiles are 5 to $10 \mathrm{~K}$ cooler than the temperatures which are reported by the other instruments.

\section{Introduction}

The Network for the Detection of Atmospheric Composition Change (NDACC; http://www.ndaccdemo.org/, last access: 3 November 2020) is an international collaboration of more than 70 research stations (Kurylo et al., 2016; De Mazière et al., 2018) which provides a common framework for the early detection of long-term changes in the atmo- 
sphere and validation of atmospheric measurements. To facilitate these instrument validation exercises, a mobile reference lidar operated by NASA's Goddard Space Flight Center (NASA GSFC Stratospheric Ozone (STROZ) lidar) is shipped around the world to conduct intensive comparison campaigns with other NDACC lidars. Most recently, NASASTROZ participated in the Lidar Validation NDACC Experiment (LAVANDE) campaign at the Observatoire de HauteProvence in southern France during July 2017 and March 2018.

A general background on ozone lidars, analysis techniques, data collection procedures, and NDACC comparison parameters of this study mirrors the work recently done during LAVANDE. For the purposes of this article, we will endeavour to provide brief but comprehensive introductions on each of these topics without engaging in onerous repetition. We invite readers seeking more details of NDACC lidar validation activities to consult the companion paper (LAVANDE; Wing et al., 2020) and other NDACC studies: STOIC (Margitan et al., 1995); OPAL (McDermid et al., 1998); OTIC (Braathen et al., 2004); NAOMI (Steinbrecht et al., 1999); HOPE (Steinbrecht et al., 2009); MOHAVE (Leblanc et al., 2011); NDACC algorithm intercomparisons for ozone lidars (Godin et al., 1999); as well as a review paper summarising NDACC validation exercises (Keckhut et al., 2004). When providing context for Hohenpeißenberg Ozone Profiling Study (HOPS) campaign, we will refer back to the 20172018 LAVANDE campaign (Wing et al., 2020) and the previous validation campaign at Hohenpeißenberg called HOPE (Hohenpeißenberg Ozone Profiling Experiment) (Steinbrecht et al., 2009).

In general, NDACC lidars measure stratospheric ozone with an accuracy better than $3 \%$ between 12 and $35 \mathrm{~km}$ altitude and better than $10 \%$ between 35 and $42 \mathrm{~km}$. NDACC lidar temperature measurements similarly have an accuracy better than $1 \mathrm{~K}$ from 30 to $40 \mathrm{~km}$ altitude when compared with co-located measurements. Lidar precision for ozone is highest near the peak concentration of ozone in the stratosphere and decreases above and below the layer as the signalto-noise ratio drops at low ozone concentrations. The precision for temperature typically decreases above $70 \mathrm{~km}$ depending on the laser power, telescope area, and integration time for a given lidar measurement. Further details on the theoretical uncertainty budgets for NDACC temperature and ozone lidars can be found in Leblanc et al. (2016a, b, c).

\subsection{Key results from HOPE}

A previous NDACC validation campaign (HOPE; Steinbrecht et al., 2009) found a low bias in the ozone profiles produced by the Hohenpeißenberg Original (HOHO) lidar between 33 and $43 \mathrm{~km}$ by up to $10 \%$ and a high bias of approximately $50 \%$ above $50 \mathrm{~km}$ when compared with the travelling standard lidar operated by NASA-STROZ. These differences were attributed to the choice of numerical filters used by the NASA and German Weather Service (DWD) algorithms. An investigation of the precision for ozone data from both lidars concluded that the agreement between profiles from each system was better than $5 \%$ between 20 and $40 \mathrm{~km}$. The 2009 HOPE campaign study also found that the HOHO lidar measures temperatures 1 to $2 \mathrm{~K}$ colder than the NASA lidar between 30 and $65 \mathrm{~km}$ and up to $15 \mathrm{~K}$ warmer than NASA above $65 \mathrm{~km}$. These differences were only significant from 25 to $50 \mathrm{~km}$. Additionally, a small altitude offset of $290 \mathrm{~m}$ was discovered and corrected in the HOHO system.

\subsection{Key results from LAVANDE}

During the more recent NDACC validation campaign by Wing et al. (LAVANDE; 2020) there was good agreement between all ozone measurements between 20 and $40 \mathrm{~km}$ with differences of less than $5 \%$ throughout this region. There were no statistically significant differences (at the $95 \%$ confidence level) between the NASA-STROZ reference lidar and the French Observatoire de Haute-Provence (OHP) $\mathrm{LiO}_{3} \mathrm{~S}$ lidar between 18 and $39 \mathrm{~km}$. Above and below this region, the percent differences increase. It is important to note that the differences in the absolute number density of the measured ozone remains low as these regions are well removed from the peak of the ozone layer. Agreement between the lidars and the Microwave Limb Sounder (MLS) and the Sounding of the Atmosphere using Broadband Emission Radiometry (SABER) satellites were also good to within $10 \%$ between 20 and $40 \mathrm{~km}$. SABER tended to produce unrealistic ozone values below $20 \mathrm{~km}$. The electrochemical concentration cell (ECC) ozonesondes were in statistical agreement (at the $95 \%$ confidence level) with both lidars between 15 and $30 \mathrm{~km}$. Above $30 \mathrm{~km}$, the uncertainties associated with the pump correction at low pressures contributed to larger measurement differences.

The temperature measurements of the NASA-STROZ reference lidar and the OHP lidar $\mathrm{LiO}_{3} \mathrm{~S}$ were statistically equal from 22 to $60 \mathrm{~km}$. Temperature is a secondary scientific product for $\mathrm{LiO}_{3} \mathrm{~S}$ which is currently not archived with NDACC or reported above $60 \mathrm{~km}$. A comparison was also conducted between NASA and the OHP temperature Lidar Température et Aérosols (LTA). The validation exercise determined that the photomultiplier in the low-gain channel of LTA was defective and the component was subsequently replaced. NASA exhibited an apparent cold bias of approximately $3 \mathrm{~K}$ below $25 \mathrm{~km}$ with respect all other instruments. Temperature agreement between the lidars and the MLS and SABER satellites was generally very good throughout the stratosphere, only exceeding $\pm 5 \mathrm{~K}$ above $55 \mathrm{~km}$. MLS exhibited a vertical oscillation in the temperature profiles with an amplitude of $\pm 5 \mathrm{~K}$ with respect to all other measurements. The characteristics of this MLS-lidar difference have been previously reported in Wing et al. (2018b). The ECC and radiosondes were also in agreement with the lidars. 
Table 1. Summary of the altitude ranges over which participating OHP and DWD lidars meet NDACC accuracy requirements at the $2 \sigma$ confidence level with respect to the travelling standard NASASTROZ lidar.

\begin{tabular}{lrr|cl|cl}
\hline & \multicolumn{2}{c|}{$\begin{array}{c}\text { Ozone } \\
\text { at 3\% }\end{array}$} & \multicolumn{2}{c|}{$\begin{array}{c}\text { Ozone } \\
\text { at 10\% }\end{array}$} & \multicolumn{2}{c}{$\begin{array}{c}\text { Temp. } \\
\text { at 1 K }\end{array}$} \\
\hline Altitude $(\mathrm{km})$ & $z_{\min }$ & $z_{\max }$ & $z_{\min }$ & $z_{\max }$ & $z_{\min }$ & $z_{\max }$ \\
\hline $\mathrm{LiO}_{3} \mathrm{~S}$ & 17 & 40 & 10 & 44 & 22 & $60^{\mathrm{a}}$ \\
$\mathrm{LTA}^{2}$ & - & - & - & - & 50 & 68 \\
$\mathrm{LiO}_{3} \mathrm{~T}$ & 13 & 14.5 & 13 & $14.5^{\mathrm{b}}$ & - & - \\
$\mathrm{HOH}$ & 17 & 41 & 15 & 41 & 17 & 78 \\
$\mathrm{HOHO}$ & 16.5 & 43 & 10 & 44 & 18 & 70 \\
\hline
\end{tabular}

${ }^{\mathrm{a}} \mathrm{LiO}_{3} \mathrm{~S}$ only reported temperatures up to $60 \mathrm{~km}$ during LAVANDE. ${ }^{\mathrm{b}} \mathrm{LiO}_{3} \mathrm{~T}$ is a tropospheric system and has minimal overlap with the stratospheric lidars.

Total uncertainty estimates for ozone and temperature were calculated for each instrument involved in the campaign. This was done in an effort to characterise the uncertainty budgets of each of the participating instruments with respect to the observed standard deviation between each set of measurements. This comparison allowed us to evaluate the uncertainty estimates for the lidars and determine if we are realistically estimating the measurement uncertainty in our instruments and the total uncertainty in our profiles of ozone and temperature. We found two outstanding issues during this exercise: (1) the temperature uncertainty budget for the $\mathrm{LiO}_{3} \mathrm{~S}$ lidar overestimates the uncertainty above $35 \mathrm{~km}$, and (2) there was a previously undetected discrepancy between the temperature uncertainty budget for the French LTA and NASA of up to $2 \mathrm{~K}$ below $50 \mathrm{~km}$. In response to the LAVANDE campaign findings, the photomultiplier tubes (PMTs) for the low-gain channels $(<50 \mathrm{~km})$ in LTA were replaced and plans were made to modify filtering codes for $\mathrm{LiO}_{3} \mathrm{~S}$ temperatures for eventual submission to the NDACC database.

\subsection{Article overview}

The HOPS campaign took place in October 2018 and March/April 2019 (see Table 2) with the dual purpose of providing an updated validation of the existing DWD ozone lidar, hereafter referred to as Hohenpeißenberg Original (HOHO), which has been in continuous operation since September 1987 (see key instrument publications: Geh, 1987; Claude et al., 1994; Steinbrecht et al., 1997, 2009) and a first validation study for the new and improved DWD ozone lidar, hereafter referred to as the Hohenpeißenberg lidar $(\mathrm{HOH})$. A technical comparison of both instruments is given in Sect. 2.2. The work presented in this article follows the NDACC standards for "blind" instrument intercomparisons. The measurements were made on site, and ozone and temperature profiles were calculated by the respective NASA and DWD lidar teams; the nightly averaged lidar pro- files were collected by an impartial NDACC referee (Sophie Godin-Beekmann) who was not involved in conducting the measurement campaign, and the intercomparison of the results was conducted by the referee's team.

The paper is structured according to the following outline: Sect. 2 introduces the instruments involved in the HOPS campaign and sets the co-location criteria for coincident measurements; Sect. 3 provides technical details for the new DWD temperature and ozone lidar and shows some examples of co-located ozone and temperature profiles; Sect. 4 conducts a statistical intercomparison between all instruments for ozone; Sect. 5 conducts a statistical intercomparison between all instruments for temperature; Sect. 6 examines and assesses the estimated uncertainty budgets for all instruments participating in the HOPS campaign; Sect. 7 conducts a cross-intercomparison of both the LAVANDE and HOPS NDACC campaigns to assess the performance of the travelling standard lidar NASA-STROZ; and Sect. 8 summarises the major finding of the HOPS NDACC intercomparison campaign as well as the results of the LAVANDE-HOPS cross-comparison and evaluation of NDACC lidar validation activities in Europe.

\section{Instruments used for HOPS}

Table 3 summarises all the different systems participating in the HOPS intercomparison. Key aspects of each different instrument are noted in each subsection. References to original or most recent instrument descriptions are given for those seeking further details and can also be found in Wing et al. (LAVANDE; 2020).

\subsection{Original DWD lidar (HOHO)}

The original DWD ozone lidar (HOHO) located at the Hohenpeißenberg Meteorological Observatory $\left(47.8^{\circ} \mathrm{N}\right.$, $11.0^{\circ} \mathrm{E}$ ) has been in continuous operation since 1987 and has one of the longest and most complete data records in NDACC. The lidar uses a differential absorption (DIAL) technique which exploits the absorption cross-sections for ozone at two different wavelengths. The first wavelength is generated using a $308 \mathrm{~nm}$ xenon chloride excimer laser. The light passes through a hydrogen $\left(\mathrm{H}_{2}\right)$ gas cell where the primary emission is used to stimulate a Raman emission at $353 \mathrm{~nm}$. Both wavelengths are transmitted through a $10 \times$ beam expander to reduce the divergence of the laser beam before transmission to the sky. The receiver telescope is a $0.6 \mathrm{~m}$ Newtonian mirror. The $353 \mathrm{~nm}$ line is weakly absorbed by ozone (also referred to as the non-absorbed line or offline) and can be used to infer the neutral density of the atmosphere above the aerosol layers present in the lower stratosphere. The shorter $308 \mathrm{~nm}$ line is more strongly absorbed by ozone (also referred to as the absorbed line or the on-line) and the lidar signals are used to detect the number of ozone 
Table 2. Measurement dates for all instruments during the HOPS campaign in October 2018 and March 2019. The dates are taken at the UT start time of the lidar measurements. $\mathrm{X}$ denotes a valid measurement for the given night.

\begin{tabular}{lcccccccc}
\hline Date & NASA & HOH & HOHO & BM & MUN & SABER & MLS & OMPS \\
\hline 21 October 2018 & X & X & X & X & X & X & X & X \\
22 October 2018 & X & X & - & - & X & X & X & X \\
21 March 2019 & - & X & X & X & X & X & X & X \\
23 March 2019 & X & X & X & - & X & X & X & X \\
28 March 2019 & X & X & - & X & X & X & X & X \\
29 March 2019 & X & X & X & - & X & X & X & X \\
30 March 2019 & X & X & X & - & X & X & X & X \\
31 March 2019 & X & X & X & X & X & X & X & X \\
1 April 2019 & X & X & X & - & X & X & X & X \\
6 April 2019 & X & X & X & X & X & X & X & X \\
\hline Total & 9 & 10 & 8 & 5 & 10 & 10 & 10 & 10 \\
\hline
\end{tabular}

Table 3. Instruments compared during the HOPS campaign in October 2018 and March/April 2019.

\begin{tabular}{|c|c|c|c|c|c|}
\hline Instrument & Measurement of ozone & $\begin{array}{l}\text { Altitude } \\
\text { range }\end{array}$ & Measurement of temperature & $\begin{array}{l}\text { Altitude } \\
\text { range }\end{array}$ & $\begin{array}{c}\text { Data } \\
\text { source }\end{array}$ \\
\hline NASA-STROZ & DIAL (308 and $355 \mathrm{~nm}$ ) & 10 to $50 \mathrm{~km}$ & Rayleigh and Raman lidar (355 nm) & 10 to $80 \mathrm{~km}$ & [1] \\
\hline $\mathrm{HOH}$ & DIAL (308 and $355 \mathrm{~nm}$ ) & 15 to $60 \mathrm{~km}$ & Rayleigh and Raman lidar (355 nm) & 15 to $90 \mathrm{~km}$ & {$[1]$} \\
\hline $\mathrm{HOHO}$ & DIAL (308 and $353 \mathrm{~nm}$ ) & 15 to $50 \mathrm{~km}$ & Rayleigh and Raman lidar (353 nm) & 15 to $70 \mathrm{~km}$ & [1] \\
\hline Brewer-Mast sondes & KI electrochemical cell & 0 to $35 \mathrm{~km}$ & Platinum resistor (RS92-SGP) & 0 to $35 \mathrm{~km}$ & [1] \\
\hline Munich radiosondes & - & - & Platinum resistor (RS41-SGP) & 0 to $35 \mathrm{~km}$ & {$[2]$} \\
\hline MLS satellite version 4.23 & $\mu$ wave limb sounding $(240 \mathrm{GHz})$ & 10 to $80 \mathrm{~km}$ & $\mu$ wave limb sounding $(118 \mathrm{GHz})$ & 15 to $90 \mathrm{~km}$ & [3] \\
\hline SABER satellite version 2.0 & IR limb sounding $(9.6,1.27 \mu \mathrm{m})$ & 15 to $90 \mathrm{~km}$ & IR limb sounding $(4.3,15 \mu \mathrm{m})$ & 10 to $100 \mathrm{~km}$ & [4] \\
\hline OMPS-LP satellite version 2.5 & Visible and UV limb sounding & 10 to $60 \mathrm{~km}$ & - & - & [5] \\
\hline
\end{tabular}

molecules in a profile above the lidar. The DIAL technique uses the logarithm of these two profiles to infer the ozone number density by taking the derivative of the ratio between these two measured profiles (Pelon and Megie, 1982). Lidar temperatures are derived using the Rayleigh returns from the $353 \mathrm{~nm}$ channel. Relative density profiles can be inferred from the range-corrected lidar photon count profile. Using an assumed a priori pressure at the top of the lidar profile, an absolute temperature profile can be calculated based on the relative density gradient. Full details of this technique are found in Hauchecorne and Chanin (1980). Below approximately $27 \mathrm{~km}$, both DWD lidars incorporate information from the local meteorological radiosonde in an effort to identify and correct for the possible contamination by stratospheric aerosol layers.

Full technical specifications can be found in Steinbrecht et al. (2009) and a comparison of the technical specifications of the original and new DWD ozone lidar can be found in Table 4.

The data processing for the $\mathrm{HOHO}$ lidar is as described in Steinbrecht et al. (2009). Lidar return signals are corrected for photon counter dead-time effects, the background is subtracted, and the signals are averaged over the night. After correction, the high-gain and attenuated low-gain signals are merged. Typically, the high-gain signal is useful down to about $20 \mathrm{~km}$ and the low-gain signal continues down to about $10 \mathrm{~km}$. From the combined signals, temperature and ozone profiles are derived. Ozone profiles typically extend down to 10 or $15 \mathrm{~km}$, depending on the night, while pure lidar temperature profiles are calculated down to $28 \mathrm{~km}$ (where aerosol becomes important and biases the retrieved temperature). The HOHO ozone algorithm uses a very wide differential filter in the ozone calculation (Godin et al., 1999; Steinbrecht et al., 2009). There is a resulting bias from the differential filter, which is substantial near $35 \mathrm{~km}$ and is corrected (see Steinbrecht et al., 2009). Corrections for signalinduced noise and timing delay are also applied in the ozone processing code as required.

\subsection{New DWD lidar (HOH)}

The newly upgraded DWD lidar also exploits the DIAL technique for measuring ozone. The key difference in the new system is the use of two lasers to generate the weakly and strongly absorbed lines in place of a Raman gas cell. The weakly absorbed line is generated at $355 \mathrm{~nm}$ from the frequency-tripled output of an Nd:YAG laser and the second wavelength at $308 \mathrm{~nm}$ is produced using an excimer gas laser. In addition to using two dedicated high-powered lasers to produce the lidar emissions, the new $\mathrm{HOH}$ lidar employs 
Table 4. Technical specifications for the lidars participating in the HOPS campaign.

\begin{tabular}{|c|c|c|c|}
\hline & NASA & $\mathrm{HOHO}$ & $\mathrm{HOH}$ \\
\hline \multicolumn{4}{|l|}{ Transmitter } \\
\hline$\lambda_{\text {on }} / \lambda_{\text {off }}$ & $308 / 355 \mathrm{~nm}$ & $308 / 353 \mathrm{~nm}$ & $308 / 355 \mathrm{~nm}$ \\
\hline Laser at $\lambda_{\text {on }}$ & Light Machinery IPEX 868 & Lambda Physik LPX 220i & Coherent LPX 210i \\
\hline Laser at $\lambda_{\text {off }}$ & Continuum 9050 & $\mathrm{H}_{2}$ Raman cell & InnoLas SpitLight 600 \\
\hline Pulse energy at $\lambda_{\text {on }} / \lambda_{\text {off }}$ & $300 / 150 \mathrm{~mJ}$ & $150 / 15 \mathrm{~mJ}$ & $200 / 120 \mathrm{~mJ}$ \\
\hline Laser rep. rate & $100 / 50 \mathrm{~Hz}$ & $35 \mathrm{~Hz}$ & $20 \mathrm{~Hz}$ \\
\hline \multicolumn{4}{|l|}{ Receiver } \\
\hline Telescope & Dall-Kirkham & Newtonian & Newtonian \\
\hline Mirror diameter & $0.76 \mathrm{~m}$ & $0.6 \mathrm{~m}$ & $1.0 \mathrm{~m}$ \\
\hline Field of view & $2.3 \mathrm{mrad}$ & $0.4 \mathrm{mrad}$ & $2 \mathrm{mrad}$ \\
\hline Focal length & $3.66 \mathrm{~m}$ & $2.4 \mathrm{~m}$ & $3 \mathrm{~m}$ \\
\hline Parallax & $0.75 \mathrm{~m}$ & $0.7 \mathrm{~m}$ & $0.8 \mathrm{~m}$ \\
\hline High- and low-gain channels & $308,355,387 \mathrm{~nm}$ & - & $308,355 \mathrm{~nm}$ \\
\hline Single channels & $332,407 \mathrm{~nm}$ & $308,353 \mathrm{~nm}$ & $332,387 \mathrm{~nm}$ \\
\hline \multicolumn{4}{|l|}{ Interference filters } \\
\hline Manufacturer & Barr Associates & Barr Associates & Barr/Williams \\
\hline Peak transmission at $\lambda_{\text {on }} / \lambda_{\text {off }}$ & $73 \% / 52 \%$ & $50 \% / 65 \%$ & $55 \% / 65 \%$ \\
\hline FWHM at $\lambda_{\text {on }} / \lambda_{\text {off }}$ & $1.1 / 0.92 \mathrm{~nm}$ & $5 / 2 \mathrm{~nm}$ & $1 / 1 \mathrm{~nm}$ \\
\hline \multicolumn{4}{|l|}{ Photon counting } \\
\hline Photo-multipliers & Hamamatsu R7400P-03 & EMI 9893QA/350 & Hamamatsu R7400P-03, R9880U-110 \\
\hline Max count rate at $\lambda_{\text {on }} / \lambda_{\text {off }}$ & $10 / 40 \mathrm{MHz}$ & $6 / 2 \mathrm{MHz}$ & $30 / 80 \mathrm{MHz}$ \\
\hline Signal-induced noise at $\lambda_{\text {on }} / \lambda_{\text {off }}$ & $500 \mathrm{~Hz} /<20 \mathrm{~Hz}$ & $<3 \mathrm{~Hz} /<0.3 \mathrm{~Hz}$ & $<20 \mathrm{~Hz} /<10 \mathrm{~Hz}$ \\
\hline Range gating & all channels & none & not used ${ }^{*}$ \\
\hline Mechanical chopper & $308 \mathrm{~nm}$ high gain & all & all \\
\hline Pre-amplifiers & - & none & $20 \times ; 1.6 \mathrm{GHz}$ \\
\hline Manufacturer & - & - & Becker\&Hickl HFAC-26 \\
\hline Multi-channel scalers & Licel $300 \mathrm{MHz}$ & Optech FDC 700 & FAST P7882-2, $200 \mathrm{MHz}$ \\
\hline
\end{tabular}

* Implemented for all channels but not used.

a $1 \mathrm{~m}$ receiver telescope, dedicated high- and low-gain channels at both 355 and $308 \mathrm{~nm}$ to improve the dynamic range of the lidar measurements, Raman channels at 332 and $387 \mathrm{~nm}$, as well as new fast-response PMTs. A secondary objective for this paper is to characterise the measurement bias and uncertainty budget of the new $\mathrm{HOH}$ with respect to the $\mathrm{HOHO}$ to ensure continuity and consistency in the Hohenpeißenberg NDACC data record.

Data processing for the new $\mathrm{HOH}$ lidar is essentially the same as for the HOHO lidar. The vertical resolutions of the derived ozone and temperature profiles (and the differential filter for ozone) are the same for $\mathrm{HOH}$ and $\mathrm{HOHO}$. The different instrumental parameters (faster counters, better timing, etc.) are accounted for in the processing. Due to the much better return signals, merging between low- and high-gain returns occurs at higher altitude, around 25 to $30 \mathrm{~km}$. Precision of the measured ozone and temperature profiles is also better than for the $\mathrm{HOHO}$ lidar. Ozone profiles from the new $\mathrm{HOH}$ lidar usually cover the altitude range from 15 to $50 \mathrm{~km}$
(10 to $45 \mathrm{~km}$ for the old $\mathrm{HOHO}$ ). Temperature profiles cover 28 to $80 \mathrm{~km}$ ( 28 to $65 \mathrm{~km}$ for the old lidar).

\subsubsection{NASA Stratospheric Ozone lidar}

NASA-STROZ is the mobile NDACC validation lidar for temperature and ozone measurements. This mobile lidar system is shipped across the world and used to run intercomparison and validation campaigns for lidar stations within the NDACC network. NASA-STROZ is a DIAL system similar to the $\mathrm{HOH}$, relying on an on-line wavelength of $308 \mathrm{~nm}$ and an off-line wavelength of $355 \mathrm{~nm}$ generated by two separate lasers. The system also has two Raman channels at 332 and $407 \mathrm{~nm}$ for tropospheric measurements. The system was constructed in 1988 (McGee et al., 1991) and has participated in many NDACC lidar campaigns for lidar stations around the world (McGee et al., 1995). 


\subsubsection{Radiosondes and Brewer-Mast ozonesondes}

Brewer-Mast (BM) ozonesondes manufactured by Mast Keystone Co. consist of a single electrochemical cell with a silver anode and platinum cathode which are immersed in a potassium iodide (KI) solution (Smit and Kley, 1998). The ozonesondes are attached to Vaisala RS92-SGP radiosondes and were launched approximately every two nights during the campaign. A total of five in situ ozone measurements were made to compare with 10 nightly average lidar profiles. Brewer-Mast ozonesonde uncertainty estimates are given as $\pm(3-5) \%$ by Stübi et al. (2008); however, we have adapted the more conservative uncertainty estimates for ECCs of $\pm(2.5-10) \%$ given by Tarasick et al. (2016).

In addition to the BMs, we have also used the Vaisala RS41-SGP meteorological radiosondes launched from the nearby station in Munich.

\subsubsection{Microwave Limb Sounder}

The MLS uses a spectrometer to make limb measurements of thermal microwave radiation of the atmosphere. The instrument, aboard the Aura satellite, allows for the retrieval of stratospheric ozone profiles with a vertical resolution of about $3 \mathrm{~km}$. Measurements of stratospheric temperature profiles are also made with a typical vertical resolution of $8 \mathrm{~km}$ at $30 \mathrm{~km}$ altitude, $9 \mathrm{~km}$ at $45 \mathrm{~km}$ altitude, and $14 \mathrm{~km}$ at $80 \mathrm{~km}$ (full width at half maximum (FWHM) of the averaging kernels; Schwartz et al., 2008). MLS profiles of temperature, geopotential height, and ozone were extracted from the version 4.0 MLS dataset. A more complete description of the instrument is given in Waters et al. (2006). For the HOPS campaign, the geopotential altitude is converted to a geometric altitude and regridded to allow for a direct comparison with the lidars and sondes.

\subsubsection{Sounding of the Atmosphere using Broadband Emission Radiometry}

Ozone and temperature measurements from the SABER instrument were downloaded from 15 to $100 \mathrm{~km}$. The vertical resolution for SABER temperature profiles is approximately $2 \mathrm{~km}$, and the estimated accuracy is 1 to $2 \mathrm{~K}$ between 15 and $60 \mathrm{~km}$ which decreases to $5 \mathrm{~K}$ near $85 \mathrm{~km}$, and to $10 \mathrm{~K}$ near $100 \mathrm{~km}$ (Rezac et al., 2015a, b). Precision estimates for SABER ozone profiles are reported as $1 \%$ between 40 and $50 \mathrm{~km}$ altitude, decreasing to $2 \%$ between 30 and $55 \mathrm{~km}$ and $10 \%$ near $80 \mathrm{~km}$ (Rong et al., 2009). A more complete description of the instrument is given in Mertens et al. (2001). SABER profiles of temperature, geopotential height, and ozone were extracted from the version 2.0 SABER dataset.

\subsubsection{The Ozone Mapping and Profiler Suite}

The Ozone Mapping and Profiler Suite Limb Profiler (OMPS-LP) on the Suomi National Polar-orbiting Partner- ship (Suomi-NPP) satellite, which has been in operation since April 2012, measures solar radiances scattered from the atmospheric limb in the ultraviolet (UV) and visible (VIS) spectral ranges. The VIS measurements are used to retrieve ozone in the lower stratosphere and are made using an ozonesensitive measurement at $602 \mathrm{~nm}$ coupled with two weakly absorbing lines at 510 and $673 \mathrm{~nm}$. The UV measurements cover the middle and upper stratosphere up to $60 \mathrm{~km}$ altitude and exploit three principal wavelengths at 302, 312, and $322 \mathrm{~nm}$, with the reference line at $353 \mathrm{~nm}$. The LP sensor has three slits separated horizontally by $4.25^{\circ}$ (about $250 \mathrm{~km}$ ), which serves to expand the cross-track coverage. The vertical sampling of OMPS-LP measurements is $\sim 1 \mathrm{~km}$, although the actual instrumental field of view is about 1.3$1.7 \mathrm{~km}$ (Flynn et al., 2006, 2014). The given vertical resolution for ozone profiles in the stratosphere is $1 \mathrm{~km}$.

The estimated uncertainty on the visible OMPS-LP ozone profile is given as a function of altitude and ranges from approximately $40 \%$ near $10 \mathrm{~km}$, to $15 \%$ at $20 \mathrm{~km}$, to roughly $3 \%$ to $5 \%$ in the rest of the stratosphere. The estimated uncertainty of the UV channel is approximately $4 \%$ at $25 \mathrm{~km}$ and drops to $2.5 \%$ at $35 \mathrm{~km}$ and is less than $2 \%$ up to $60 \mathrm{~km}$ (Loughman et al., 2005; Zawada et al., 2018). In this study, we use version 2.5 OMPS-LP ozone profiles described in Kramarova et al. (2018).

OMPS ozone profiles were not included in the LAVANDE study as at the time the authors considered the temporal offset too large. In HOPS, we are making a first attempt at using a solar limb-scanning satellite to validate nighttime lidar measurements.

\subsubsection{Co-locating satellite profiles and ground-based profiles}

For HOPS, we considered all satellite profiles with a tangent point within $\pm 5^{\circ}$ latitude and $\pm 15^{\circ}$ longitude of the Hohenpeißenberg Meteorological Observatory $\left(47.8^{\circ} \mathrm{N}, 11.0^{\circ} \mathrm{E}\right)$ and within $\pm 6 \mathrm{~h}$ of 00:00 UTC ( $1 \mathrm{~h}$ after local midnight for the lidar measurements nights) for SABER, $\pm 99 \mathrm{~min}$ of 01:40 UTC for MLS, and \pm 101 min of 11:50 UTC the following day for OMPS. This fairly large coincidence box is depicted in Fig. 1. It covers most of central Europe, from Wales in the northwest to Bulgaria in the southeast. The box size chosen here is similar to the compromise chosen in Wing et al. (2018b) and relates to the trade-off between a small number of close overpasses and a larger number of overpasses which may be further away from the ground station. For HOPS, there are typically between 10 and 20 coincident profiles for each of the satellites. These profiles are generally divided between one or two satellite overpasses for a given night (the following morning for OMPS). 


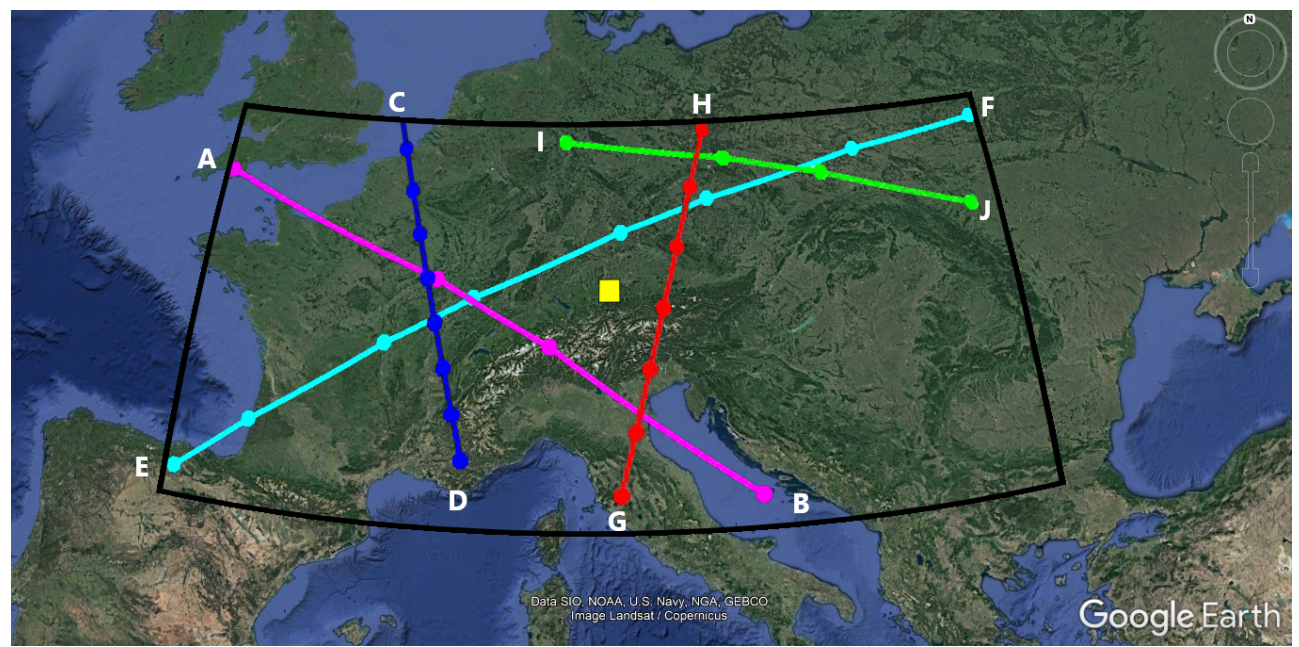

Figure 1. The area defined for coincident measurements during the HOPS campaign (42.8, -4.0-52.8, 26.0). The Hohenpeißenberg Meteorological Observatory is represented by the yellow square at $(47.8,11.0)$, and the nearby Munich-Oberschleißheim radiosonde launches are located at $(48.1,11.3)$. For the night beginning on 29 March 2019, the HOH lidar operated from 21:28-04:40 UTC; the MLS overpass (G-H, red) occurred at approximately 01:14 UTC on 30 March; the SABER overpasses occurred on 29 March at 22:45 UTC (E-F, cyan) and 23:30 UTC (A-B, magenta), and on 30 March at 01:16 UTC (I-J, green); and the OMPS overpass (C-D, blue) occurred on 30 March at 11:50 UTC (data: (C) Google Earth Pro, 2020).

\section{DWD NDACC lidar upgrades and example data}

The HOPS campaign took place in two parts: the first period covered the nights of 21 and 22 October 2018, and the second period covered nights in 2019, from 21 March to 6 April. Table 2 shows which systems provided ozone and/or temperature profiles on each of the different nights of the campaign. Table 3 shows the details of the altitude range and important wavelengths for each instrument when making measurements of temperature and ozone.

\subsection{Evaluation of the new $\mathrm{HOH}$ lidar}

The HOPS campaign provided a perfect opportunity to conduct an evaluation of the newly installed $\mathrm{HOH}$ lidar. The $\mathrm{HOH}$ lidar ran concurrently with the NASA-STROZ mobile validation lidar as well as the original HOHO lidar. This crucial overlap period allows us the opportunity to conduct a formal NDACC evaluation of the Hohenpeißenberg lidars and ensure that there are no unexplained biases or problems which could go on to cause discontinuities in one of the longest-running NDACC datasets (1987-2020). Table 4 shows an in-depth comparison of the technical specification for the $\mathrm{HOH}, \mathrm{HOHO}$, and NASA lidars.

Figure 2 shows a comparison of the nightly average deadtime-corrected photon count rates for the high-gain channels of the $\mathrm{HOH}$ and $\mathrm{HOHO}$ lidars as well as the ratio of the high- and low-gain channels for both systems. The lefthand panel shows the photon count rates (PCRs) for the highgain channels in both lidars at 308 and $355 \mathrm{~nm}$. The signal in the $308 \mathrm{~nm}$ channel for the $\mathrm{HOH}$ lidar (red) is 74 times larger than the signal in the $308 \mathrm{~nm}$ channel of $\mathrm{HOHO}$ (blue). Similarly, the high-gain $355 \mathrm{~nm}$ channel of $\mathrm{HOH}$ (green) has 224 times more signal than the $353 \mathrm{~nm}$ high-gain channel in HOHO (magenta). The signal improvements in the low-gain channels at both wavelengths (not shown) are not indicative of the general increase in system performance as there are neutral density filters placed in front of the photomultipliers to attenuate the signals. The increased signal-to-noise (SNR) ratio of the $\mathrm{HOH}$ system with respect to the $\mathrm{HOHO}$ system results in ozone profiles with less statistical uncertainty (discussed later in Sect. 6.1), and the large factor-of-224 improvement in the high-gain $355 \mathrm{~nm}$ channel will allow for Rayleigh temperature profiles to routinely reach the upper mesosphere and lower thermosphere (UMLT).

The right-hand panel of Fig. 2 shows that there is significant improvement in the SNR of the high-gain $308 \mathrm{~nm}$ channel (dark red) above $55 \mathrm{~km}$. The high-gain channel at $355 \mathrm{~nm}$ (dark blue) is linear over the entire altitude range. The ratio between the low-gain channels for both $308 \mathrm{~nm}$ (dark green) and $355 \mathrm{~nm}$ (dark purple) has small slopes which indicates very slight offsets in the slopes of the PCR profiles. It is recommended that either the attenuation of the low-gain channels be reduced or that the high-gain channels be truncated at a lower altitude to provide a greater overlap region between the high- and low-gain channels where both have high SNR.

In the crucial ranges between 30 and $50 \mathrm{~km}$ for ozone and 30 and $70 \mathrm{~km}$ for temperature the $\mathrm{HOH}$ channels are linear with respect to their $\mathrm{HOHO}$ counterparts and do not appear to exhibit altitude-dependent biases or photomultiplier saturation effects. This is an important result to document with regards to the long-term stability of the NDACC lidar tem- 

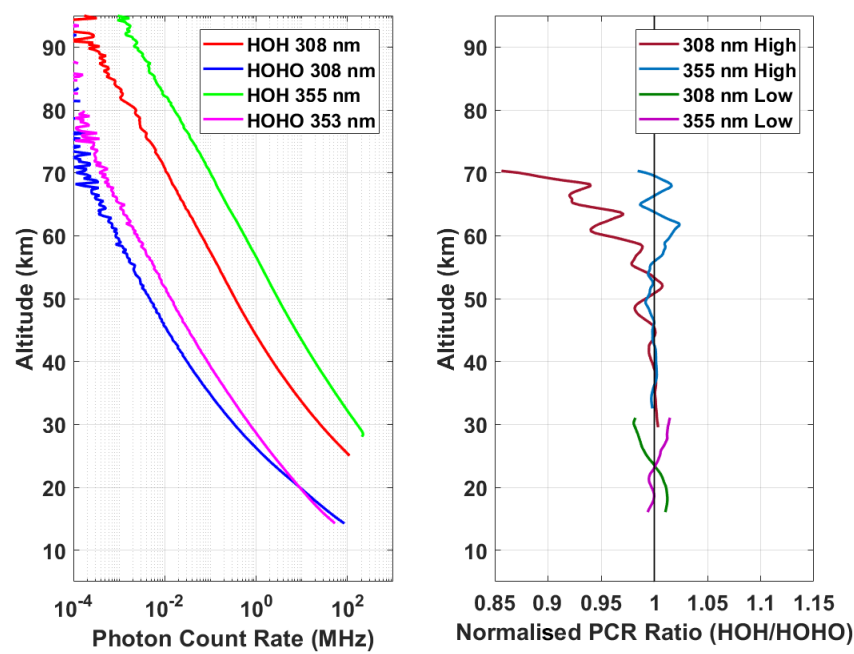

Figure 2. High-gain signals for the $\mathrm{HOH}$ and $\mathrm{HOHO}$ lidars showing higher signal levels in the newly improved $\mathrm{HOH}$ lidar. Ratios of high- and low-gain signals for the $\mathrm{HOH}$ and $\mathrm{HOHO}$ lidars showing SNR improvement in received signal.

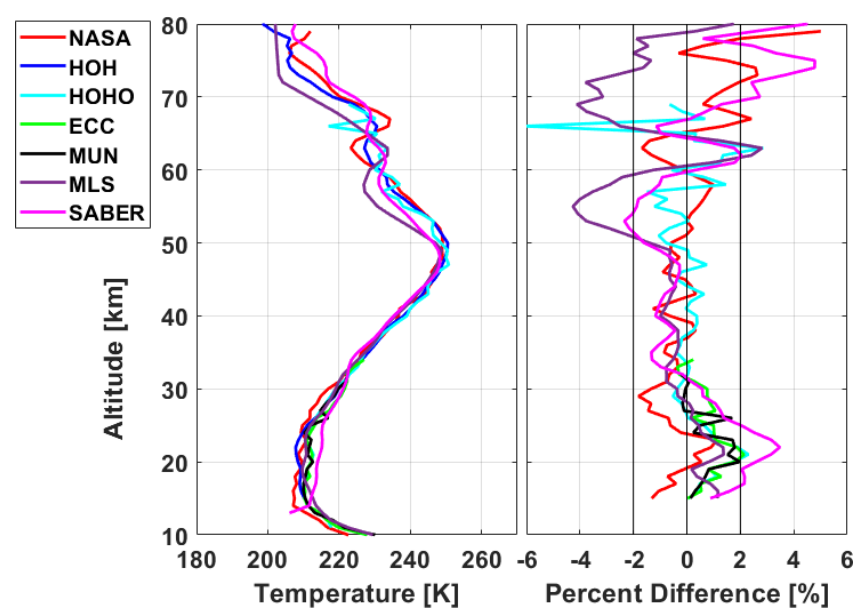

Figure 3. Temperature profiles measured by the NASA-STROZ (red), $\mathrm{HOH}$ (blue), and $\mathrm{HOHO}$ (cyan) lidars, locally launched ozonesonde (green), Munich meteorological radiosonde (black), and overpasses from MLS (violet) and SABER (magenta) on the night of 21 October 2018. Percent differences are with respect to the $\mathrm{HOH}$ lidar.

perature and ozone dataset at the Hohenpeißenberg Meteorological Observatory.

\subsection{Example comparisons of temperature and ozone profiles}

Examples of both temperature and ozone profiles made during the HOPS campaign by each of the instruments are given in Figs. 3 and 4, respectively. Differences are taken with respect to the measured ozone and temperature from the $\mathrm{HOH}$ lidar when all instruments were in operation.

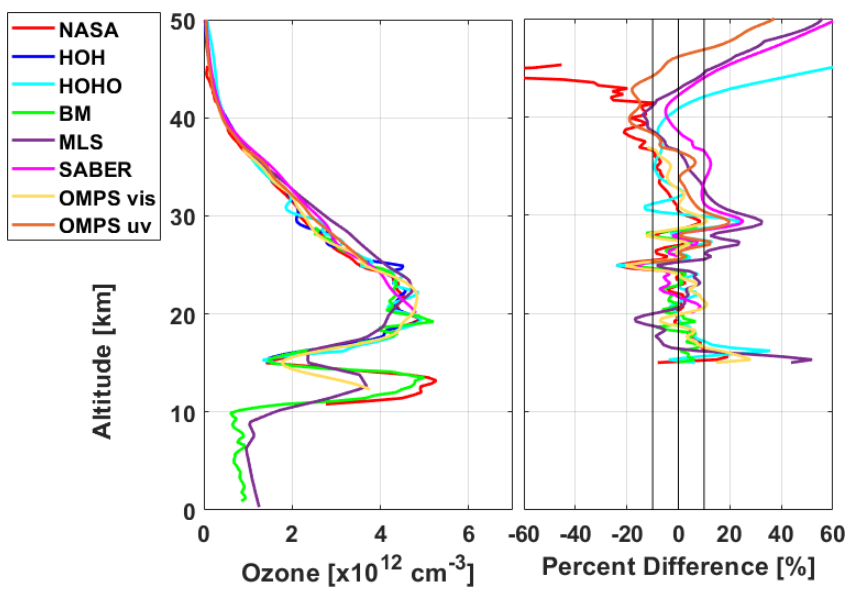

Figure 4. Ozone profiles measured by the NASA-STROZ (red), $\mathrm{HOH}$ (blue), and HOHO (cyan) lidars, locally launched ozonesonde (green), and overpasses from SABER (magenta), MLS (violet), OMPS VIS (mustard), and OMPS UV (burnt orange) on the night of 6 April 2019. Percent differences are with respect to the $\mathrm{HOH}$ lidar.

The temperatures shown in the left-hand panel of Fig. 3 were measured on 21 October 2018 and all follow the expected profile for the middle atmosphere. There is very close agreement between 30 and $50 \mathrm{~km}$ in the stratosphere with slightly more variation below $20 \mathrm{~km}$ and in the mesosphere. A closer examination of the temperature differences of each instrument with respect to the $\mathrm{HOH}$ lidar is shown in the right-hand panel of Fig. 3. To calculate the differences, all measurements were adapted to a standard $1 \mathrm{~km}$ grid. Below $20 \mathrm{~km}$, it is expected that geophysical differences in the sampled air masses will have a larger impact on the differences with the stationary lidars than in the middle atmosphere. Additionally, the uncertainty of the satellite measurements at low altitudes, advection of the balloon sondes, and possible contamination of the lidar signal by aerosols may all contribute to the observed differences. Above the stratopause, located near $50 \mathrm{~km}$, there is again a greater chance that geophysical variability is contributing to the observed lidarsatellite differences. Above $60 \mathrm{~km}$, the signal-to-noise ratio of the HOHO lidar (cyan) becomes the largest contributor to the observed differences.

Similarly, an example of nightly average ozone profiles for the night of 6 April 2019 (7 April 2019 for OMPS) is given in the left-hand panel of Fig. 4. We can see that all instruments accurately reproduce the shape of the stratospheric ozone layer and also identify a ozone laminae near $13 \mathrm{~km}$. The $\mathrm{HOH}$ and $\mathrm{HOHO}$ lidars report ozone profiles for altitudes greater than $15 \mathrm{~km}$. In the right-hand panel of Fig. 4, all profiles were adapted to a common $300 \mathrm{~m}$ grid and compared with the ozone profile measured by the $\mathrm{HOH}$ lidar. Below $25 \mathrm{~km}$, there is very good agreement between all instruments with differences of generally less than $10 \%$. The 
lowest couple of data points for the $\mathrm{HOH}$ lidar near $15 \mathrm{~km}$ may underestimate the ozone number density on this particular night. SABER ozone was cut at $20 \mathrm{~km}$, as below this point the profile number densities became unrealistically large. Above $28 \mathrm{~km}$, there is increased variability (expressed as percent difference) between the lidars and the satellites which is likely a function of low ozone number densities and geophysical variability. Above $40 \mathrm{~km}$, the percent difference between the different measurements is not a useful metric, as small absolute differences in the ozone number density can translate to very large percent differences. We will provide various other metrics later in the article when we discuss the systematic bias of ozone measurements in this region.

\section{Intercomparison results for ozone}

Figure 5 shows a time series of ozone number densities measured by each of the different systems used in the HOPS campaign. The ozone profiles of each instrument were integrated to $2 \mathrm{~km}$ resolution before being plotted. The top panel, which shows the ozone number densities at $40 \mathrm{~km}$, indicates that in 2019 (last eight nights) there was tight clustering of all the measurements except for OMPS, which was consistently low, and the NASA lidar, which was significantly lower on three of the nights. During the 2018 portion of the campaign (first two nights), there was more variation between all instruments. In the second panel, which shows ozone densities at $30 \mathrm{~km}$, we see that there is tight clustering for all instruments except for the OMPS visible channel. Given that the OMPS UV channel is in closer agreement with all of the other measurements and that the OMPS visible channel only extends to $35 \mathrm{~km}$, it is probable that the observed low bias in OMPS visible is associated with the upper measurement limits of that channel. The ozonesonde on 31 March appears to be an outlier, and it is likely that well-known pump problems at low pressures are the cause. The third panel at $20 \mathrm{~km}$ also shows very tight clustering between all instruments with a slight high bias beginning to be seen in SABER data. The NASA lidar experienced technical difficulties on 21 March 2019 and did not produce an ozone profile for the night. Additionally, there was a substantial delay in starting the $\mathrm{HOHO}$ lidar compared to the $\mathrm{HOH}$ lidar. As a result, the $\mathrm{HOHO}$ nightly average profile was more heavily influenced by a transient ozone layer which was present on this night (not shown). The bottom panel at $15 \mathrm{~km}$ shows a higher level of inter-measurement variability between the lidars and satellites as the geophysical variability and sampling uncertainty become evident. SABER clearly shows a high bias with respect to other instruments at this altitude.

A more systematic look at the ensemble ozone number density differences between the $\mathrm{HOH}$ lidar measurements and the measurements made by each of the other instruments is shown in Fig. 6. The darkened line represents the mean difference for each pair of measurements and the shaded region

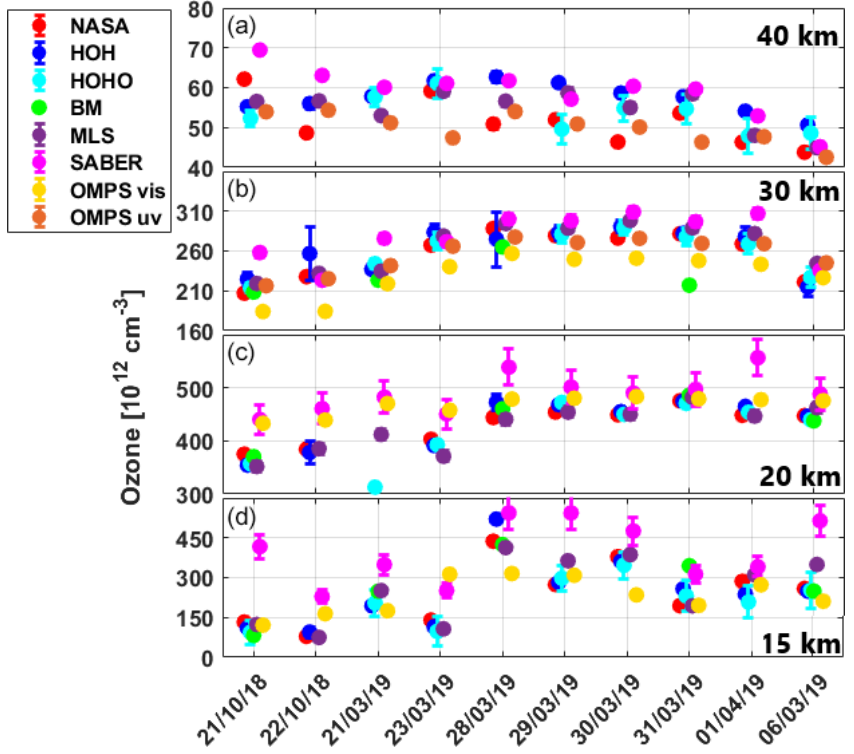

Figure 5. Time series of ozone measurements smoothed using a $2 \mathrm{~km}$ boxcar average. Panel (a) contains ozone densities at $40 \mathrm{~km}$, panel (b) at $30 \mathrm{~km}$, panel (c) at $20 \mathrm{~km}$, and panel (d) at $15 \mathrm{~km}$.

is the $2 \sigma$ (95\% confidence level) limit. The best agreement between the different ozone systems is found between 20 and $40 \mathrm{~km}$ altitudes where differences are generally less than $\pm 10 \%$. The larger deviation in the OMPS VIS profile (mustard) above $28 \mathrm{~km}$ is likely an indication that we should rely on the OMPS UV channel (burnt orange) above this height, while the sharp decrease in the Brewer-Mast profile (green) above $30 \mathrm{~km}$ arises from errors in the BM pump corrections at low pressure. Below $20 \mathrm{~km}$, there are larger differences between the satellites and the lidars (and sondes). For MLS (violet) and OMPS VIS (mustard), this is likely due to geophysical differences in the sampled air masses, while for SABER (magenta) there is a definite bias in the data. In general, the results shown in Fig. 8 are similar to the results of shown in Fig. 7 of the LAVANDE study and to previous NDACC intercomparisons. Above $40 \mathrm{~km}$, there is an unexplained low bias of approximately $25 \%$ in the OMPS UV channel (burnt orange) and $35 \%$ in the NASA-STROZ ozone densities with respect to all other measurements. Some of the bias at this altitude may be the same as the documented low bias of $8 \%-$ $25 \%$ in OMPS UV ozone with respect to co-located profiles from OSIRIS, MLS, and ACE (Kramarova et al., 2018).

Figure 7 shows the correlation, with respect to the $\mathrm{HOH}$ lidar, of each data point for each of the involved HOPS instruments as a function of ozone number density. To determine the correlation, we have used the Pearson correlation coefficients which are a measure of the linear correlation between two datasets. The correlation coefficients are calculated by dividing the covariance between any two datasets by the product of the standard deviations of each dataset. In the left-hand panel, showing measurements from 15 to 


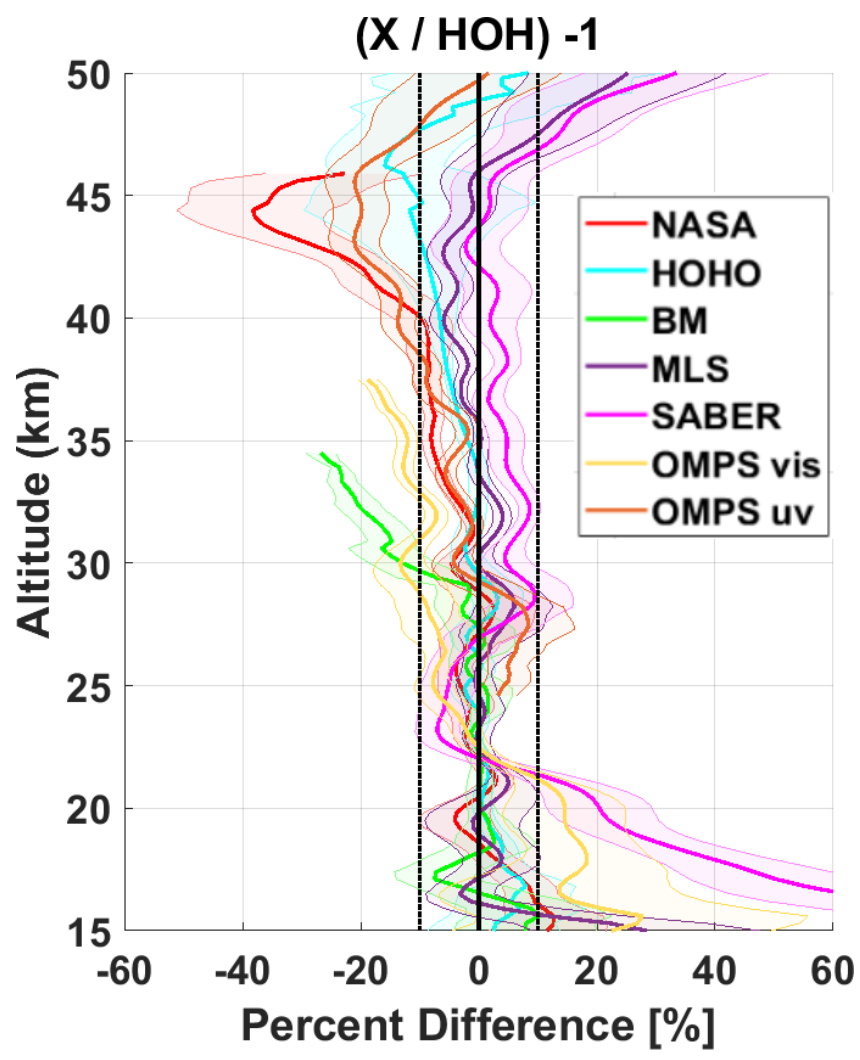

Figure 6. The average relative difference profile between the ozone profiles measured by the various HOPS instruments compared to the ozone profile measured by the $\mathrm{HOH}$ lidar. The shaded range gives the \pm 2 standard deviations of the mean and indicates the statistical confidence interval at the $95 \%$ uncertainty level.

$20 \mathrm{~km}$, we see that NASA-STROZ (red), HOHO (cyan), the ozonesonde (green), and OMPS (yellow) all closely track the ozone number densities measured by the $\mathrm{HOH}$ lidar. The spread in the values is roughly symmetric about the reference line. MLS (violet) tends to report significantly higher values than all other instruments when measuring ozone number densities less than $3 \times 10^{12} \mathrm{~cm}^{-3}$, which is consistent with the results of Fig. 8 in the Wing et al. (LAVANDE; 2020) study. SABER (magenta) ozone number densities are significantly larger than all other measurements below $20 \mathrm{~km}$ and quickly become unreliable at lower altitudes (not shown). The central panel, showing measurements from 20 to $30 \mathrm{~km}$, likewise shows very little scatter for all instruments except for MLS and SABER. The increased scatter may be due to geophysical variability. The right-hand panel shows the scatter for all instruments from 30 to $50 \mathrm{~km}$, and we can clearly see the outlier data points in the Brewer-Mast (green) which likely arise from instrumental problems.

Examining the correlation between each of the instruments in the HOPS campaign and the $\mathrm{HOH}$ lidar adds another facet to our understanding of the intercomparison. By examining the "goodness" of the match as a function of altitude (shown in Fig. 8), we can examine the difference between measurements while taking into account the statistical scatter as well as any covariances. Unsurprisingly, the best correlation with the $\mathrm{HOH}$ lidar is the HOHO lidar (cyan) with correlation coefficients greater than 0.95 below $35 \mathrm{~km}$. Above this altitude, the drop in the SNR of the HOHO lidar contributes to a rapid decrease in the correlation. In the same altitude range, MLS (violet) and the NASA-STROZ lidar (red) also show very high correlations greater than 0.85 . At higher altitudes, the SNR of NASA decreases the correlation to a minimum of 0.5 near $45 \mathrm{~km}$, while the SNR of the $\mathrm{HOH}$ lidar and geophysical variability gradually reduce the correlation with MLS. The correlation with the Brewer-Mast (green) is very high at low altitude and gradually descends as the pump correction becomes less reliable at lower pressures. The correlation of SABER (magenta) exhibits the "S shape" seen in the LAVANDE study with a dip in the correlation values near $25 \mathrm{~km}$ near the maximum of the ozone concentration. This drop occurs when the instrument is not accurate enough to detect the very small changes in ozone density. The correlation profile for OMPS VIS (mustard) increases with altitude and smoothly merges with the correlation profile of the OMPS UV (burnt orange). The maximum correlation for OMPS should be read as 0.84 at $30 \mathrm{~km}$ as we have more confidence in the UV channel in the middle and upper stratosphere. There are two possible explanations for why the OMPS correlation is smaller than that of the MLS. First, there is a significant time offset between the nightly lidar measurements and the OMPS overpass which happens on the morning after. Second, as will be discussed in Fig. 14, the visible channel of OMPS has a very large estimated uncertainty below $20 \mathrm{~km}$.

\section{Intercomparison results for temperature}

We have conducted a similar analysis for HOPS temperature measurements to that done in the previous section for ozone. Figure 9 shows the temperature time series at four altitudes for each of the different systems during HOPS.

The top panel of Fig. 9 traces temperatures in the mesosphere at $70 \mathrm{~km}$. At these altitudes, we can see the contribution that larger temperature uncertainties in the lidars (particularly HOHO; cyan) introduce to the time series. In general, all three lidars (NASA, $\mathrm{HOH}$, and $\mathrm{HOHO}$ ) report higher temperatures than the satellites (MLS and SABER). This result is consistent with LAVANDE as well as other European lidar-satellite comparisons (Wing et al., 2018, b).

The second panel of Fig. 9 traces temperatures at $50 \mathrm{~km}$, near the altitude associated with the stratopause. With the exception of 21 March 2019, when the lidars and satellites produce very different measured temperatures, the lidars and satellites generally produce similar temperatures, with the satellites being $\sim 5 \mathrm{~K}$ cooler than the lidars. 


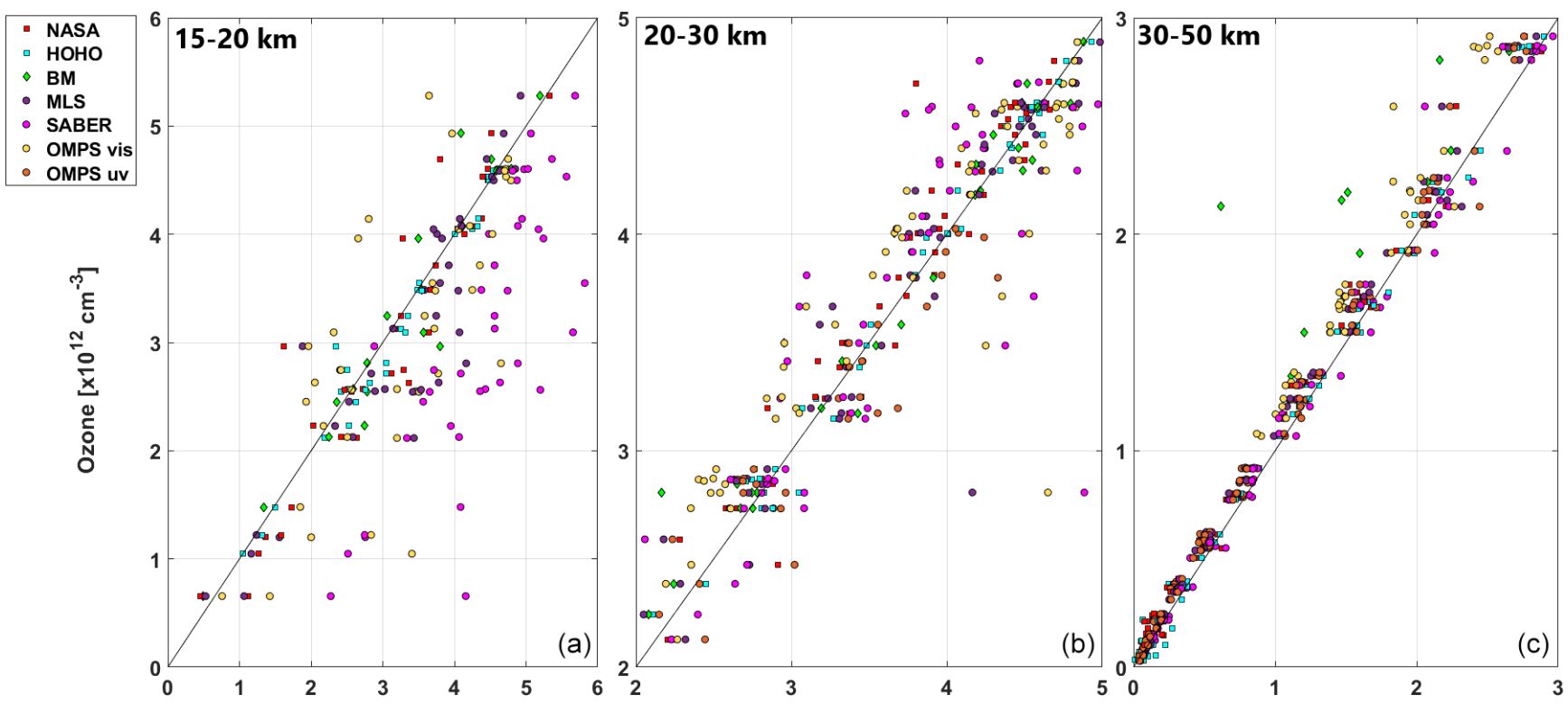

Figure 7. Ozone scatter plots, smoothed using a $2 \mathrm{~km}$ boxcar average, with respect to ozone number densities from the $\mathrm{HOH}$ lidar: (a) 15 to $20 \mathrm{~km}$; (b) 20 to $30 \mathrm{~km}$; (c) 30 to $50 \mathrm{~km}$.

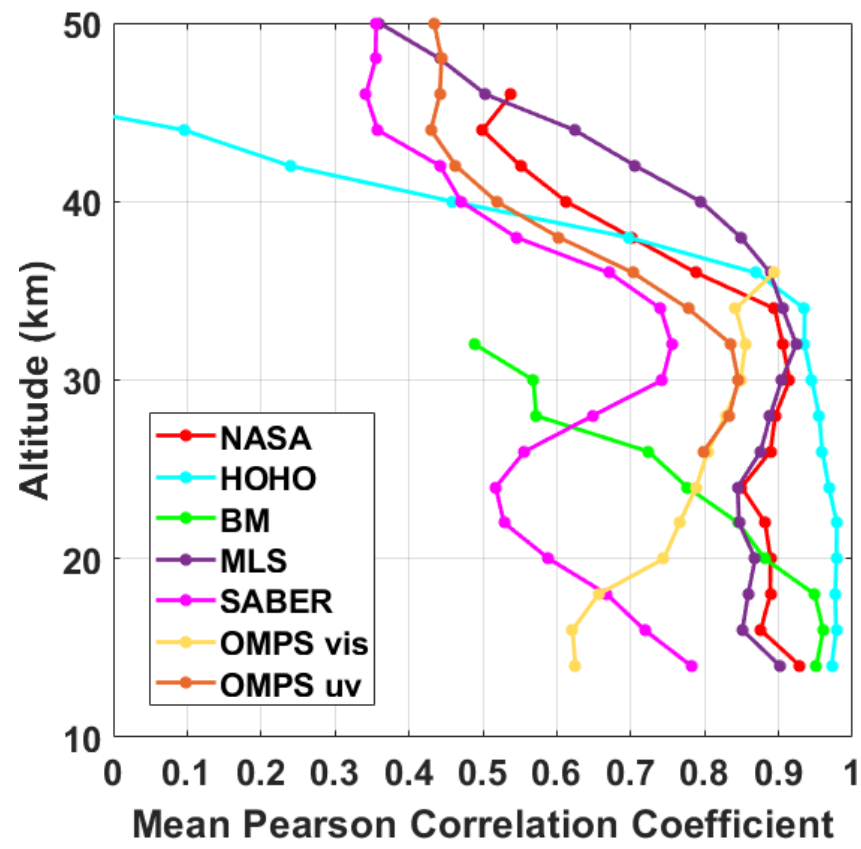

Figure 8. Vertical profiles of the correlation coefficient calculated for ozone concentrations measured by the various HOPS instruments with respect to $\mathrm{HOH}$ measurements. Correlation is taken over the 10 nights of the HOPS campaign data vertically integrated to $2 \mathrm{~km}$.

The third panel of Fig. 9 traces temperatures in the lower stratosphere and shows the best agreement between all measurements. We expect that the temperature at these altitudes would show very little variability due to the high SNR in

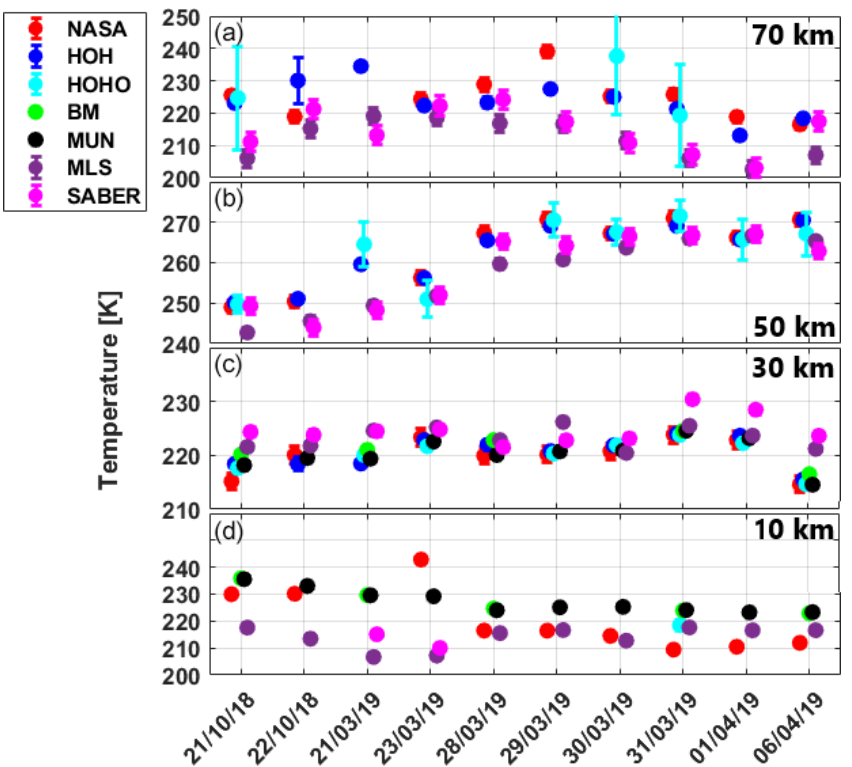

Figure 9. Time series of temperature measurements at smoothed using a $2 \mathrm{~km}$ boxcar average. Panel (a) contains temperatures at $70 \mathrm{~km}$, panel (b) at $50 \mathrm{~km}$, panel (c) at $30 \mathrm{~km}$, and panel (d) at $10 \mathrm{~km}$.

all instruments as well as the low geophysical variability in lower stratospheric temperatures on hourly timescales. SABER (magenta) appears as an outlier from 31 March to 6 April 2019. The average spatiotemporal offset of the SABER profiles from the Hohenpeißenberg Meteorological Observatory is not significantly different from 21 to 30 March 2019. 
The bottom panel of Fig. 9 traces temperatures at $10 \mathrm{~km}$ in the UTLS. At this altitude, there are fewer measurements, more geophysical variability associated with passing weather fronts, variability associated with the advection of balloon measurements, and possible bias introduced into the lidar temperatures from aerosol contamination. Despite the increased variability, we can see that the NASA lidar (red), SABER (magenta), and MLS (violet) generally measure colder temperatures than the meteorological radiosonde from the Munich station (black) and the locally launched Brewer-Mast sonde (green). It is interesting to note that the two balloon sonde measurements agree very well despite the $65 \mathrm{~km}$ separation between Hohenpeißenberg and Munich.

The average temperature difference between all instruments participating in the HOPS campaign and the NASA lidar is given in Fig. 10. The differences between the temperatures produced by the three lidars are less than $\pm 5 \mathrm{~K}$ from 15 to $80 \mathrm{~km}$. The temperature differences between $\mathrm{HOH}$ and NASA (red) are only significant below $18 \mathrm{~km}$ and above $78 \mathrm{~km}$. The NASA temperatures appear to have a slight cold bias below $30 \mathrm{~km}$, which is consistent with the results from LAVANDE described in the introduction Sect. 1.2. MLS (violet) becomes significantly different from the other measurements above $55 \mathrm{~km}$ and exhibits a vertically oscillating temperature bias described in (Wing et al., 2018b). SABER (magenta) exhibits a significant warm bias between 15 and $25 \mathrm{~km}$ with respect to lidar measurements which has been previously been identified in the SABER temperature assessment paper (Remsberg et al., 2008).

Figure 11 shows the scatter between nightly temperature comparisons during the HOPS in three panels. The left-hand panel shows the differences between temperatures from each instrument and the $\mathrm{HOH}$ lidar temperatures in the UTLS from 10 to $35 \mathrm{~km}$. The scatter shows fairly close agreement to the black $1: 1$ reference line, particularly for the in situ temperatures from the sondes. NASA (red) exhibits slightly colder temperatures, and the MLS (violet) and SABER (magenta) satellites have slightly warmer temperatures. The centre panel shows the scatter from 35 to $60 \mathrm{~km}$ in the upper stratosphere and stratopause region. The temperatures from NASA fall very closely along the reference line; however, the temperatures from HOHO (cyan) exhibit more variation associated with the drop in SNR in that system. The satellites have a very high level of temperature variation but appear to be centred about the reference line. In the right-hand panel, the temperature scatter from 60 to $90 \mathrm{~km}$ is shown. The temperature variance is largest at these altitudes; however, despite the increased scatter, we can see the systematic cool bias of the satellites and warm bias of NASA with respect to $\mathrm{HOH}$.

Figure 12 shows profiles of the mean Pearson correlation coefficient of HOPS instrument temperatures with respect to temperatures from the $\mathrm{HOH}$ lidar, similar to what was done for ozone. Below $32 \mathrm{~km}$, we see very high correlation between the two balloon sondes and the HOHO lidar, all three

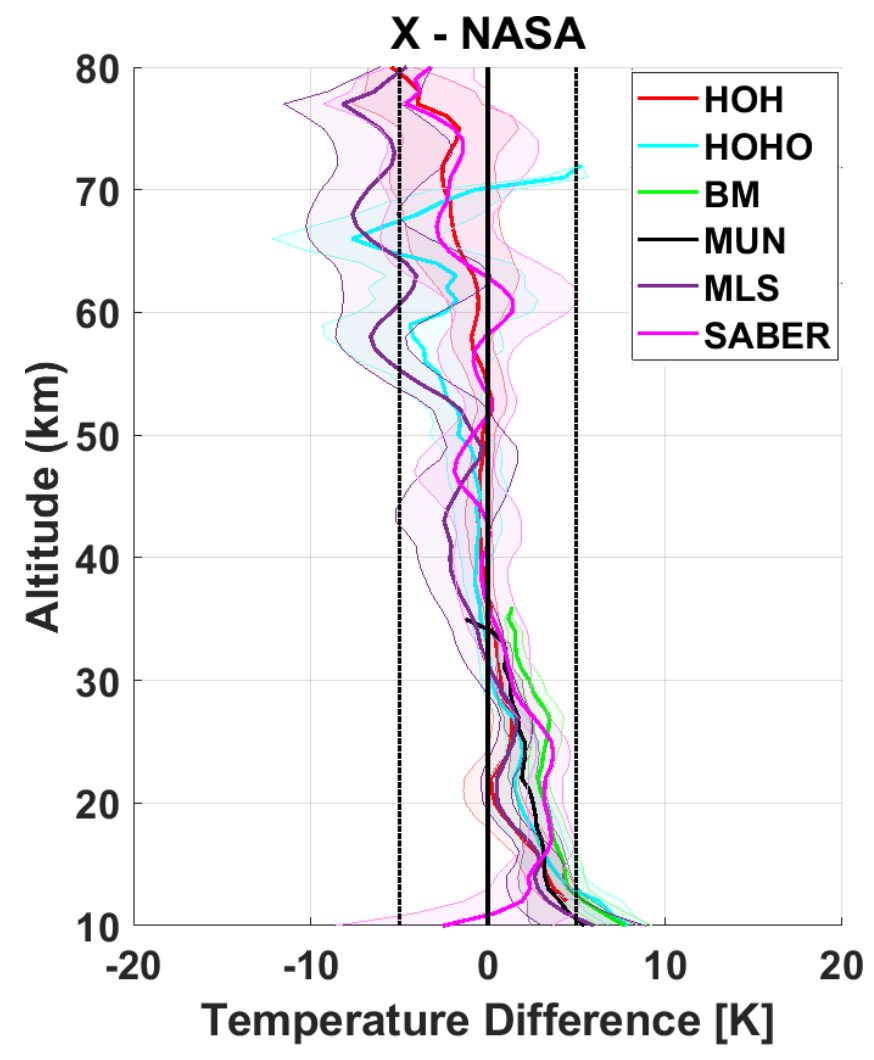

Figure 10. Average absolute differences with respect to the NASA temperature profile measured during the HOPS campaign. The shaded range gives \pm 2 standard deviations of the mean and indicates statistical uncertainty at the $95 \%$ confidence level.

of which show correlations larger than 0.85 . The HOHO lidar reaches a maximum correlation with $\mathrm{HOH}$ of 0.98 near 35 , which slowly declines with altitude as the SNR of HOHO approaches 1 . The correlation profile of the NASA lidar temperatures is unique in that there is lower correlation from 15 to $30 \mathrm{~km}$. This drop may be due to the combination of $\mathrm{HOH}$ lidar data with the radiosonde mentioned in Sect. 2.1, differences in the overlap correction between the two lidar systems, the use of Raman temperature channels in the NASASTROZ lidar, or geophysical sampling problems arising from a few nights where the DWD lidars measured longer than the NASA system. Disentangling the source of the disagreement is beyond the scope of a "blind intercomparison" and would require each team to reprocess their data. In Sect. 6, we will discuss the disagreement between the observed differences between NASA and $\mathrm{HOH}$ and the differences that we should expect given the reported uncertainty budgets of each system. From 35 to $58 \mathrm{~km}$, the correlation between NASA and $\mathrm{HOH}$ temperatures is very high at nearly 0.99 . Above $60 \mathrm{~km}$, the statistical variation and the differences in filtering could reduce the value of the correlation. Both MLS and SABER have very similar correlation profiles with respect to the $\mathrm{HOH}$ lidar temperatures. There is a local minimum in 

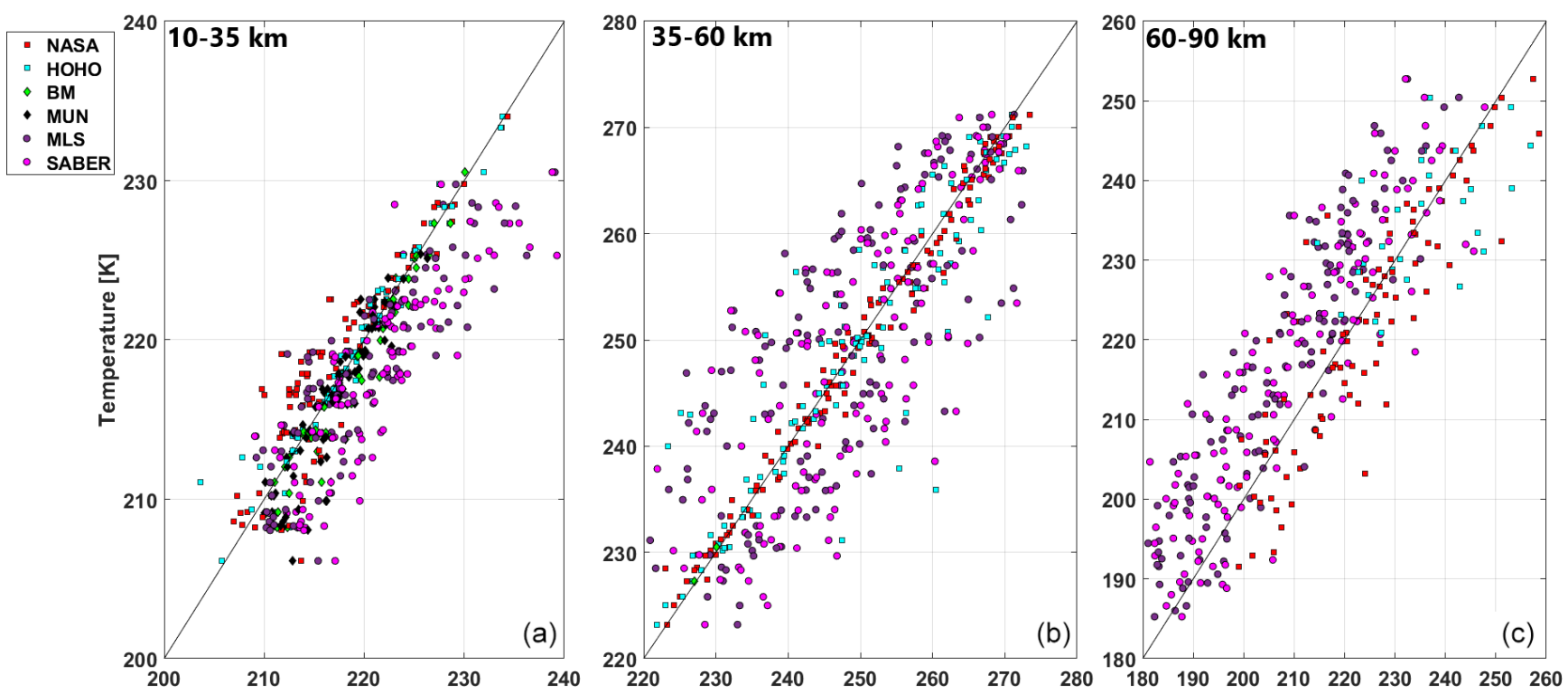

Figure 11. Scatter plots of temperature at $2 \mathrm{~km}$ resolution for the different instruments involved in the HOPS campaign with respect to the HOH lidar: (a) 10 to $35 \mathrm{~km}$; (b) 35 to $60 \mathrm{~km}$; (c) 60 to $90 \mathrm{~km}$.

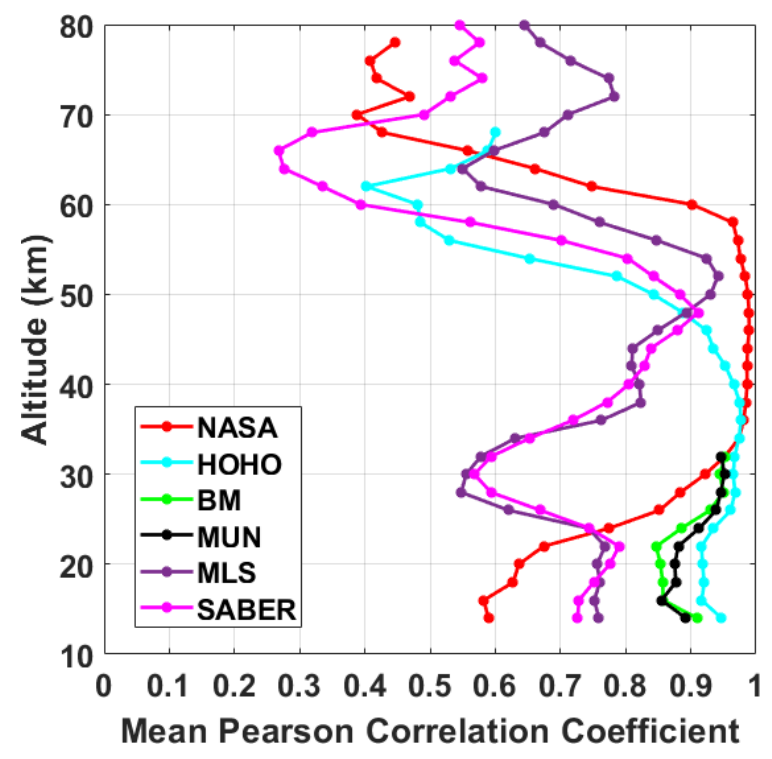

Figure 12. Vertical profiles of the correlation between temperatures reported by the various HOPS systems with respect to the $\mathrm{HOH}$ lidar temperature profiles.

both profiles near $30 \mathrm{~km}$ which is associated with the low geophysical variance between different measurements and even lower reported uncertainties at the start of the stratosphere. The general drop in correlation coefficients for all measures above 50 to $60 \mathrm{~km}$ can be attributed to the increase in both the measurement variance and the drop in SNR for the lidar systems.

\section{Intercomparison of uncertainty estimates}

When comparing the published uncertainty estimates for lidars, sondes, and satellites during an intercomparison it is not sufficient to rely simply on the reported instrument precision. Some instruments report full uncertainty budgets, others average accuracy, and others single-profile precision. To make the comparison fair, we have taken the average of the total nightly uncertainty for each instrument and normalised it with respect to the nightly average measurement to arrive at a plot estimating the average relative uncertainty as a function of altitude during HOPS. This follows the same method used in LAVANDE.

For the lidars, the largest terms in the uncertainty budgets are the statistical uncertainty arising from the Poisson counting statistics for photon detection which become large at higher altitudes. Several other smaller corrections with respect to atmospheric scattering and transmission, instrument corrections, and algorithm initialisation (temperature only) are also included in the formal "NDACC" uncertainty budget described in detail in Leblanc et al. (2016a, b, c). In this blind intercomparison, we take the reported total uncertainty or "NDACC" uncertainty reported for by each group. In Fig. 13, we can see that the average of the nightly relative uncertainty for temperature in the NASA (red), $\mathrm{HOH}$ (blue), and $\mathrm{HOHO}$ (cyan) lidars are typically less than $1 \%$ over most of the measurement range. The $\mathrm{HOHO}$ lidar which has a less powerful laser output at $353 \mathrm{~nm}$ (refer to the introduction in Sect. 3.1 and the discussion of Fig. 2) reaches $1 \%$ relative uncertainty at $45 \mathrm{~km}$ - much lower than the $\mathrm{HOH}$ and NASA lidars. The sudden drop in the relative uncertainty in all three lidar profiles near $25 \mathrm{~km}$ is associated with the transition 


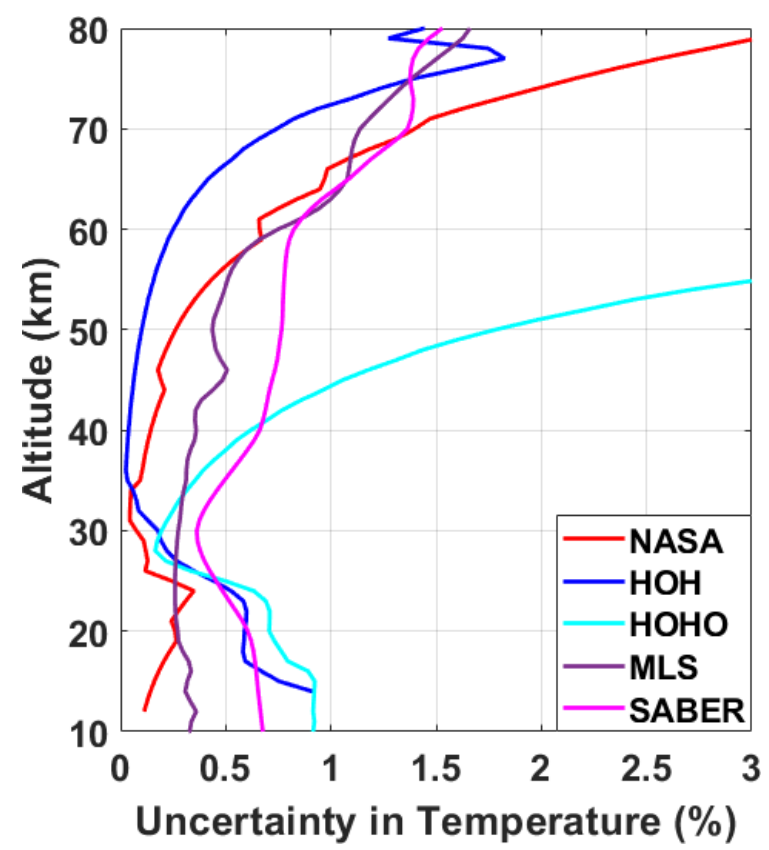

Figure 13. Relative uncertainties in temperature for all HOPS instruments.

from the low-gain lidar channels to the high-gain lidar channels. The nightly uncertainty profiles for MLS (violet) and SABER (magenta) were downloaded directly with the temperature profiles. Temperature uncertainties for the Vaisala RS41-SGP radiosonde used at both the Munich radiosonde station and the Vaisala RS92-SGP attached to the BrewerMast launched at Hohenpeißenberg are given as $0.15 \mathrm{~K}$ below $100 \mathrm{hPa}$ and $0.3 \mathrm{~K}$ above $100 \mathrm{hPa}$. We have not included these values in Fig. 13 as they are too small to be clearly distinguishable.

The major term in the uncertainty budget for the lidar ozone measurements comes from the Poisson photon counting uncertainty. A full and detailed propagation of uncertainty through the lidar equation is given in Godin et al. (1999). In Fig. 14, we see different behaviours in the relative uncertainty of the NASA (red) and the uncertainties and the $\mathrm{HOH}$ (blue) and HOHO (cyan) lidars. The peak in relative uncertainty between 25 and $30 \mathrm{~km}$ in both DWD lidars is due to the transition between the low-gain and high-gain lidar channels. It is recommended that the DWD lidars merge their high- and low-gain channels at a lower altitude to suppress the uncertainty peak in this range. The ozone uncertainty in the Brewer-Mast is given simply as $\pm 3 \%-5 \%$. This flat uncertainty profile does not capture the observed variance between the Brewer-Mast measurement and the lidars which is discussed in the next section. We have chosen to include an uncertainty profile estimated for the ECC (green) by Tarasick et al. (2016) which presents a more realistic uncertainty profile for a similar instrument. The relative uncertainty profiles for MLS (violet) and SABER (magenta) were calculated us-

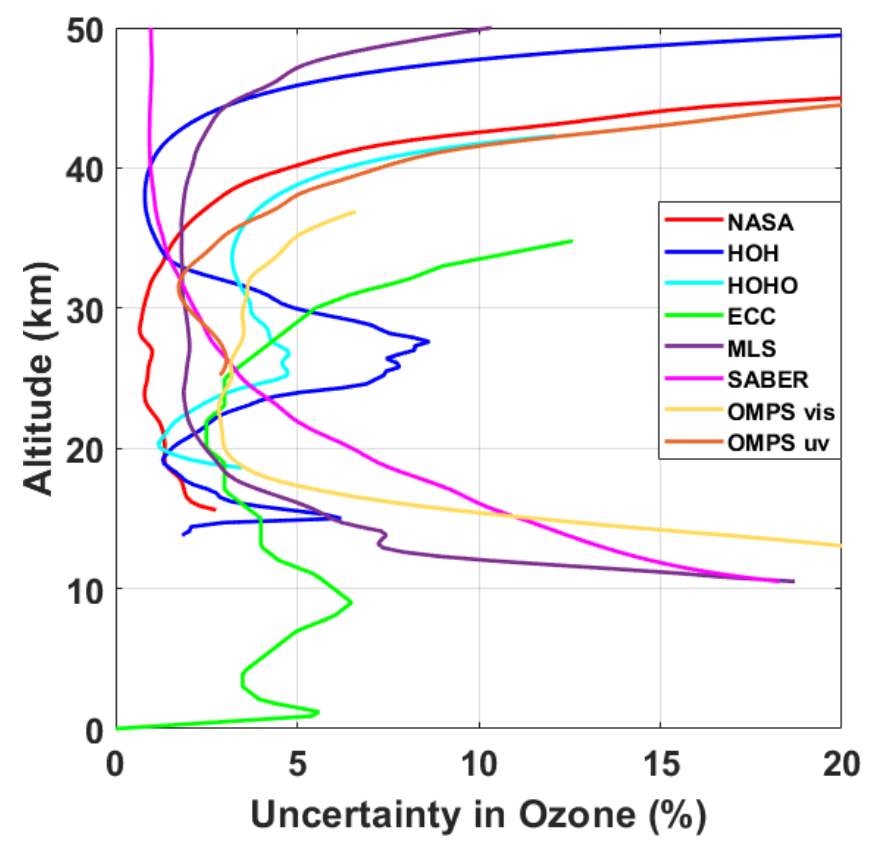

Figure 14. Relative uncertainties in ozone for all HOPS instruments.

ing the uncertainty information included in the downloaded data files. MLS has low relative uncertainty throughout most of the stratosphere, averaging $2 \%$ to $3 \%$. The uncertainty rapidly increases at low ozone densities below $20 \mathrm{~km}$ and above $45 \mathrm{~km}$. SABER ozone uncertainty appears unrealistic above $35 \mathrm{~km}$ and increases rapidly below $30 \mathrm{~km}$. We have endeavoured to estimate accurate profiles of OMPS relative uncertainty for both the visible channel and the UV channel for the HOPS campaign. Using the $1 \sigma$ measurement uncertainty estimates found in Loughman et al. (2005); Zawada et al. (2018); Kramarova et al. (2018), we have calculated the nightly relative uncertainty profiles for OMPS visible (mustard) and UV channels (burnt orange). We have doubled the $1 \sigma$ values and then averaged the nightly relative uncertainty profile for HOPS to generate an uncertainty profile which is consistent with the other participating measurements at $2 \sigma$. This value is approximately $3 \%$ for the OMPS visible channel between 20 and $30 \mathrm{~km}$. The relative uncertainty rises drastically below $18 \mathrm{~km}$ and increases slightly above $32 \mathrm{~km}$. Likewise, the relative uncertainty profile for the UV channel of OMPS uses the reported $1 \sigma$ precision and accuracy estimates by Loughman et al. (2005) between $1 \%$ and $3 \%$ to calculate the relative uncertainty profile in Fig. 14 (burnt orange). The rapid increase in relative uncertainty seen in the OMPS UV channel above $35 \mathrm{~km}$ results from the rapid decrease in ozone number density and the possible low bias of OMPS UV data seen in Fig. 6. 

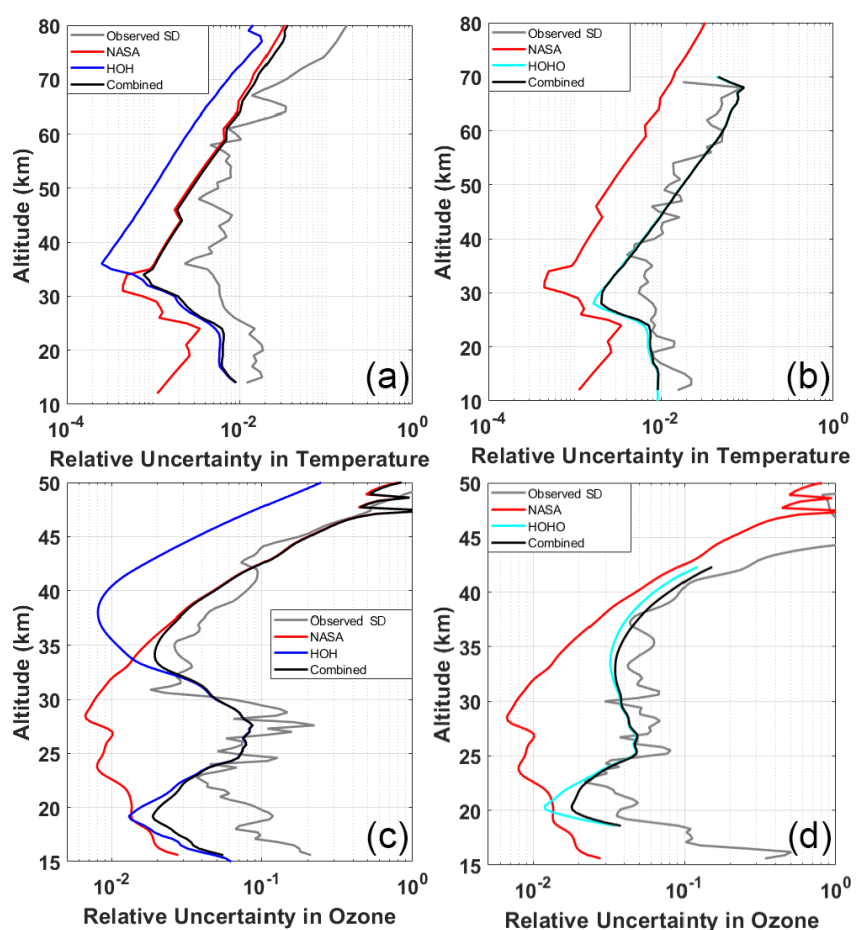

Figure 15. Comparison of relative uncertainties in both temperature and ozone for the NASA (red), $\mathrm{HOH}$ (blue), and $\mathrm{HOHO}$ (cyan) lidar systems.

\subsection{Assessment of the uncertainties reported by the instruments}

Here, we conduct an intercomparison of the reported uncertainty budgets for all HOPS lidars for both temperature and ozone. This exercise is important for establishing that the total uncertainty budgets for NDACC lidars are realistic and keep with NDACC guidelines and standards. For lidar-lidar comparisons, there is nearly perfect spatiotemporal coincidence, and we can neglect geophysical variations in our uncertainty comparison. Here, we will use the NASA-STROZ (red) average relative uncertainty profile as the reference. Following the same statistical comparison technique used in the companion Wing et al. (2020) article, we will assume that there is no correlation between the average measurement noise for the lidars. In Fig. 15, the measurement uncertainties of NASA-STROZ lidar, $\sigma_{\mathrm{N}}\left(\right.$ red), $\mathrm{HOH}$ lidar, $\sigma_{\mathrm{H}}$ (blue), and $\mathrm{HOHO}$ lidar, $\sigma_{\mathrm{Ho}}$ (cyan) are plotted alongside the combined uncertainty, $\sigma_{\text {combined }}$ (black), given in Eq. (2), and the relative standard deviation of the measurement differences, $\sigma_{\mathrm{RSD}}$ (grey), given in Eq. (1). In these equations, $N_{i}$ describes the NASA measurement, $\bar{N}$ describes the average NASA measurement, $\sigma_{\mathrm{N}}$ describes the measurement uncertainty for NASA, $X_{i}, \bar{X}$, and $\sigma_{X}$ describe same properties for the HOPS instrument under consideration, and $n$ is the total number of measurements.

$\sigma_{\mathrm{RSD}}=\sqrt{\left(\frac{1}{n-1}\right) \Sigma\left(\left(\frac{X_{i}}{N_{i}}\right)-\left(\frac{\bar{X}}{\bar{N}}\right)\right)^{2}}$

If the combined uncertainty estimates expressed in Eq. (2) (black) are correct, they should be similar to the observed standard deviation of all the nightly mean ozone profile differences, $\sigma_{\mathrm{RSD}}$ (grey), expressed in Eq. (1).

$\sigma_{\text {combined }}=\frac{\bar{X}}{\bar{N}} \sqrt{\left(\frac{\sigma_{X}}{\bar{X}}\right)^{2}+\left(\frac{\sigma_{\mathrm{N}}}{\bar{N}}\right)^{2}}$

Figure 15 compares the average relative uncertainties for the three lidars participating in the HOPS campaign for both temperature and ozone. In panel (a), we see the comparison of the relative temperature uncertainty for the NASA (red) and $\mathrm{HOH}$ (blue) lidars. Above $35 \mathrm{~km}$, the combined uncertainty budget (black) is dominated by NASA, which has a smaller receiver telescope than the $\mathrm{HOH}$ lidar (see Table 4), which results in a reduced photon count rate at higher altitudes. Below $35 \mathrm{~km}$, the $\mathrm{HOH}$ lidar has the larger contribution to the combined relative uncertainty budget arising from increased measurement uncertainty in the low-gain $355 \mathrm{~nm}$ channel. When comparing the combined estimated relative uncertainty (black) with the observed standard deviation (grey), we see that below $55 \mathrm{~km}$ there is variance between the lidar temperature measurements which cannot be explained by the combined uncertainty budget. A nearly identical result was found in the LAVANDE study with unexplained variance in the temperatures below $55 \mathrm{~km}$ between NASA and the OHP lidars, LTA, and between NASA and $\mathrm{LiO}_{3} \mathrm{~S}$.

In panel (b), the uncertainty of the HOHO lidar (cyan) is the largest contributor to the combined estimated relative uncertainty budget (black). The combined uncertainty accounts for most of the observed variance in the comparison with NASA (grey), except for a discrepancy between 25 and $35 \mathrm{~km}$. This region appears to be directly above the transition from the low-gain to high-gain channels in the HOHO lidar and the estimation of the HOHO uncertainty in this region may not be complete. Taken together with our interpretations of the LAVANDE results and the results shown in Fig. 15a, we begin to see a pattern of increased variability between lidar measurements in the region surrounding the transition between high- and low-gain channels, which is not fully accounted for the NDACC uncertainty budget.

Panel (c) shows the relative uncertainty in ozone for NASA (red), HOH (blue), combined uncertainty (black), and observed variation between measurements (grey). As was previously stated, the differences between the estimated relative uncertainty profiles for the NASA and $\mathrm{HOH}$ lidars arise from the transition from the low-gain to high-gain channels in the DWD lidars. The observed variance is well represented by the combined uncertainty above $23 \mathrm{~km}$. From 15 to $23 \mathrm{~km}$, 
there is more variation in the data than can be accounted for in the uncertainty estimates of either lidar. One possible explanation for the increased variability below $25 \mathrm{~km}$ is sampling time. On a few nights, the NASA-STROZ lidar measured for a set number of hours while the DWD lidars measured for the entire night. Given that this is a "blind intercomparison", we cannot reprocess the data; however, in future NDACC validation exercises, we strongly encourage participating PIs to end measurements at the same time or submit partial files to the NDACC referee. Below $25 \mathrm{~km}$, there is sufficient geophysical variation that a few hours of extra measurements can change the nightly mean profile.

Panel (d) shows the ozone relative uncertainty estimates from NASA (red) and HOHO (cyan). Similar to the results in panel (b), the combined uncertainty and observed standard deviation are dominated by the uncertainty estimates of the less powerful $\mathrm{HOHO}$ lidar.

\subsection{Uncertainty evaluation of the satellites}

In the LAVANDE companion paper, we attempted to separate the measurement uncertainty associated with each profile taken during a satellite overpass, the sampling uncertainty associated with the variation between individual profiles included in the average satellite overpass, and the geophysical variability. It was correctly pointed out that characterisations of sampling uncertainty are not completely independent of geophysical variability. For the HOPS intercomparison of lidar-satellite relative uncertainty estimates, we have not attempted to address sampling uncertainty. In all cases where the observed standard deviation of the differences between observations (grey) is larger than the combined NASA-satellite-estimated uncertainty budget (black), we will interpret the difference as "geophysical variability" with the understanding that there is some unknown contribution associated with the accuracy of the satellite measurement.

In Fig. 16a and b, we can see that below approximately $70 \mathrm{~km}$ the combined uncertainty budget is mostly due to the contributions of the MLS (violet) and SABER (magenta) measurement uncertainties respectively. Above this altitude, the statistical measurement uncertainty in the lidar temperature measurements become larger than the measurement uncertainty in the satellites

Figure $16 \mathrm{c}, \mathrm{d}$, e, and $\mathrm{f}$ show the relative uncertainty estimates for ozone for NASA (red) with MLS (violet), SABER (magenta), the OMPS visible channel (mustard), and the OMPS UV channel (burnt orange), respectively. For MLS and SABER comparisons, the satellite measurement uncertainty estimates are larger than the lidar uncertainty estimates below 30 to $35 \mathrm{~km}$, with the opposite holding true at higher altitudes. In panel (e), the measurement uncertainty in OMPS VIS (mustard) is much larger than the measurement uncertainty in the lidar and accounts for nearly all the observed variation (grey). The OMPS UV measurement uncertainty
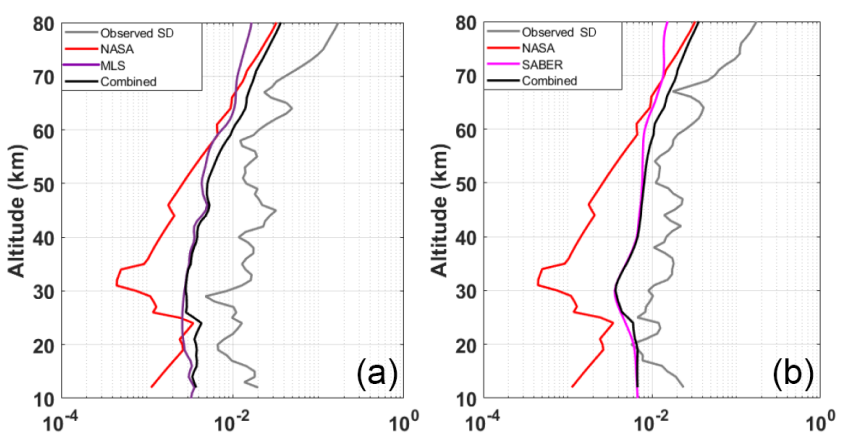

Relative Uncertainty in Temperature
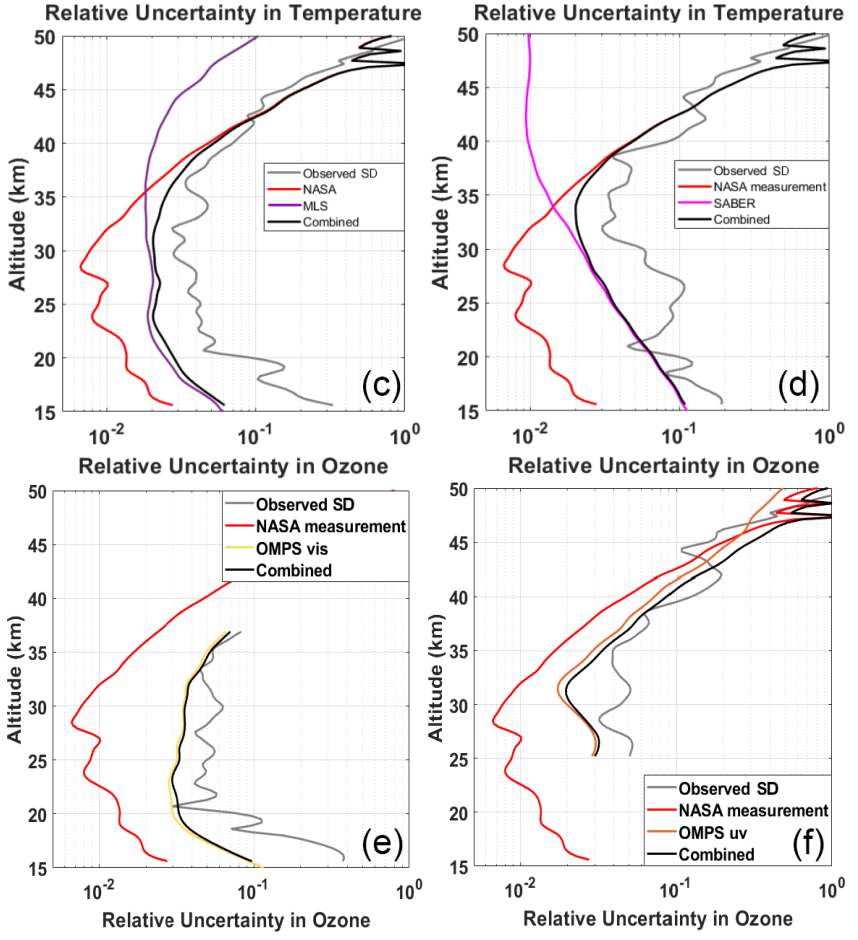

Figure 16. Comparison of relative uncertainties in both temperature and ozone for the NASA lidar (red), MLS (violet), SABER (magenta), OMPS visible (mustard), and OMPS UV (burnt orange).

(burnt orange) shown in panel (f) is comparable to the lidar measurement uncertainty above $45 \mathrm{~km}$ and is larger than the lidar measurement uncertainty at lower altitudes.

\subsection{Uncertainty evaluation of the balloon sondes}

The temperature measurement uncertainty for NASA lidar (red) and the balloon-borne in situ measurements (green), shown in Fig. 17a, are very similar in magnitude. However, the combined uncertainty (black) is consistently less than the observed standard deviation between the lidar and sonde temperature measurements (grey). We expect that the majority of the difference-observed variation below $20 \mathrm{~km}$ is likely due to the geophysical variability inherent in sampling different air masses, while variability in ozone above $27 \mathrm{~km}$ likely arises from problems with the ozonesonde pump or poor pump corrections. Figure 17b shows that the combined ozone 

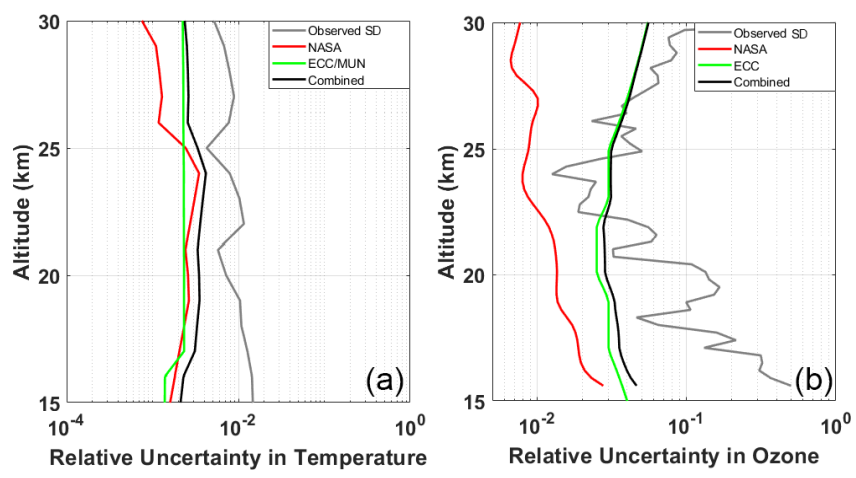

Figure 17. Comparison of relative uncertainties in both temperature and ozone for the RS41-SGP/RS92-SGP and ECC sondes.

uncertainty (black) overestimates the observed standard deviation between 22 and $26 \mathrm{~km}$ and severely underestimates the variation at lower altitudes. Recall that we have used the ECC uncertainty reported by Tarasick et al. (2016) in place of the reported $3 \%$ to $5 \%$ uncertainty associated with the BrewerMast. Given that the ECC uncertainty is $2.5 \%$ at $25 \mathrm{~km}$ and $4 \%$ at $15 \mathrm{~km}$, the generic Brewer-Mast uncertainty profile would further overestimate the combined uncertainty above $22 \mathrm{~km}$. A better estimation of measurement uncertainty for the Brewer-Mast instrument is required for the HOPS campaign.

\section{Cross-intercomparison with results obtained during the LAVANDE campaign}

Since 2018, substantial work has been done to validate European NDACC lidar activities using the travelling standard NASA-STROZ lidar. Given that the LAVANDE and HOPS campaigns were conducted one after another, we are presented with the opportunity to conduct a crossintercomparison analysis of the NASA-STROZ lidar as well as make some comments on how the five NDACC stratospheric lidars (NASA, $\mathrm{LiO}_{3} \mathrm{~S}$, LTA, $\mathrm{HOH}$, and $\mathrm{HOHO}$ ) have compared against the satellite and sonde measurements.

Figure 18 shows the average percent difference in ozone profiles for all instruments during both the LAVANDE and HOPS intercomparison and validation campaigns (except the tropospheric ozone lidar at $\mathrm{OHP}, \mathrm{LiO}_{3} \mathrm{~T}$ ). Panel (a) shows the average differences between NASA and $\mathrm{LiO}_{3} \mathrm{~S}$ (blue), $\mathrm{HOH}$ (red), and $\mathrm{HOHO}$ (cyan). Above $40 \mathrm{~km}$, NASA consistently reports lower ozone densities than the three other stratospheric ozone lidars. Below $20 \mathrm{~km}$, NASA reports higher ozone densities than the DWD lidars ( $\mathrm{HOH}$ and $\mathrm{HOHO}$ ) but lower densities than $\mathrm{LiO}_{3} \mathrm{~S}$ at OHP. Between 20 and $32 \mathrm{~km}$, all lidars report statistically identical ozone number densities.

Panel (b) shows the average ozone differences between the NASA lidar and the ozonesonde measurements. The ECC (green) was flown during the LAVANDE campaign at OHP, while the Brewer-Mast (red) was flown during the HOPS campaign at Hohenpeißenberg. Below $20 \mathrm{~km}$, NASA reports lower ozone densities than the ozonesondes; however, this is only significant below $15 \mathrm{~km}$ for the ECC. During the LAVANDE campaign, the ozonesondes were in significantly better agreement with the OHP lidar $\mathrm{LiO}_{3} \mathrm{~S}$ than with the NASA lidar below $17 \mathrm{~km}$, and similarly during the HOPS campaign the ozonesondes were in better agreement with the $\mathrm{HOH}$ and $\mathrm{HOHO}$ lidars than with the NASA lidar; however, this result is not significant. Above $30 \mathrm{~km}$, the ozonesondes diverge from both the lidar and satellite measurements during both campaigns.

Panel (c) shows the average ozone differences between the NASA lidar and SABER during LAVANDE (blue) and HOPS (red). Above 40 to $45 \mathrm{~km}$, SABER ozone measurements report higher ozone densities than any of the NDACC lidars. In addition, below $25 \mathrm{~km}$, SABER ozone profiles become undependable.

Panel (d) shows the average ozone differences between the NASA lidar and MLS during LAVANDE (magenta) and HOPS (green). Above 40 to $45 \mathrm{~km}$, MLS ozone measurements report higher ozone densities than any of the NDACC lidars. Below 15 to $17 \mathrm{~km}$, NASA and $\mathrm{LiO}_{3} \mathrm{~S}$ report lower ozone number densities than MLS, while $\mathrm{HOH}$ and $\mathrm{HOHO}$ report slightly higher ozone densities.

Figure 19 shows the average absolute temperature difference between all instruments during both the LAVANDE and HOPS campaigns. Panel (a) shows the average differences between NASA and $\mathrm{LiO}_{3} \mathrm{~S}$ (blue), LTA (green), $\mathrm{HOH}$ (red), and $\mathrm{HOHO}$ (cyan). Above approximately $60 \mathrm{~km}$, NASA consistently reports warmer temperatures than three of the other temperature lidars $\left(\mathrm{LiO}_{3} \mathrm{~S}\right.$ truncates temperature profiles at $60 \mathrm{~km}$ ). This warm bias is significant with respect to the OHP temperature lidar LTA above $65 \mathrm{~km}$. Below $20 \mathrm{~km}$, the NASA lidar reports colder temperatures than both the $\mathrm{LiO}_{3} \mathrm{~S}$ and $\mathrm{HOH}$ lidars. As was previously reported in Wing et al. (2020), the OHP temperature lidar was discovered to have a faulty photomultiplier tube in the low-gain channel (0 to $50 \mathrm{~km}$ ) which accounts for the warm bias between 30 and $50 \mathrm{~km}$. The LAVANDE study allowed us to identify and replace this faulty component, and the subsequent temperatures no longer show this bias. LTA temperatures below $30 \mathrm{~km}$ have an aerosol-induced cold bias which is more pronounced for temperature lidars operating at $532 \mathrm{~nm}$ than for lidars at $355 \mathrm{~nm}$.

Panel (b) shows the average temperature differences between the NASA lidar and the sonde measurements. The temperatures from the ECC which was flown with MeteoModem M10 radiosondes (green) and Brewer-Mast flown on a Vaisala RS92-SGP (red) are shown. At all altitudes, the NASA lidar has a slight cold bias of between 2 and $4 \mathrm{~K}$.

Panel (c) shows the average temperature differences between the NASA lidar and SABER during LAVANDE (blue) and HOPS (red). There appears to be a general trend where NASA temperatures have a 0 to $5 \mathrm{~K}$ cold bias below $40 \mathrm{~km}$ 

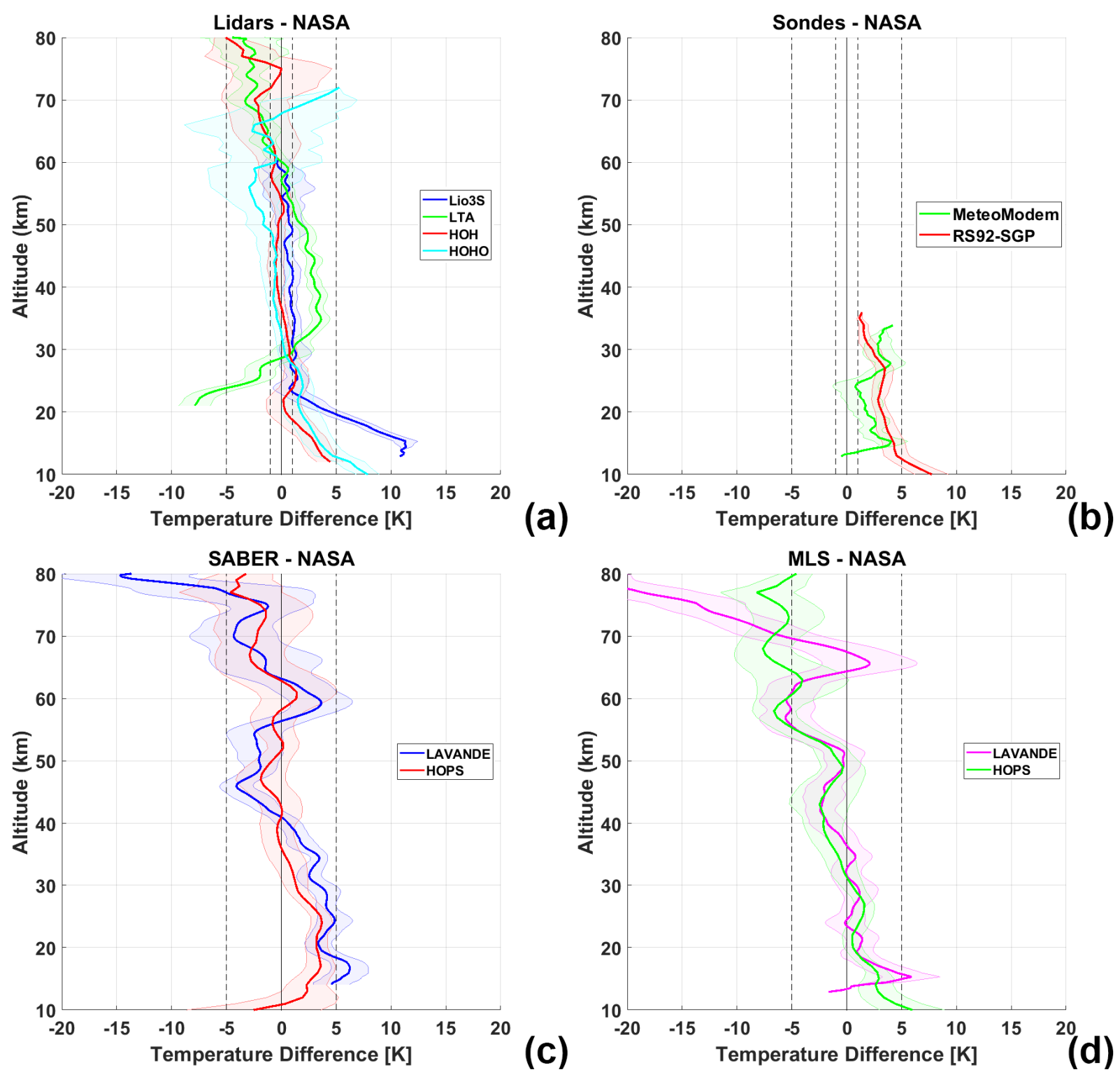

(a)

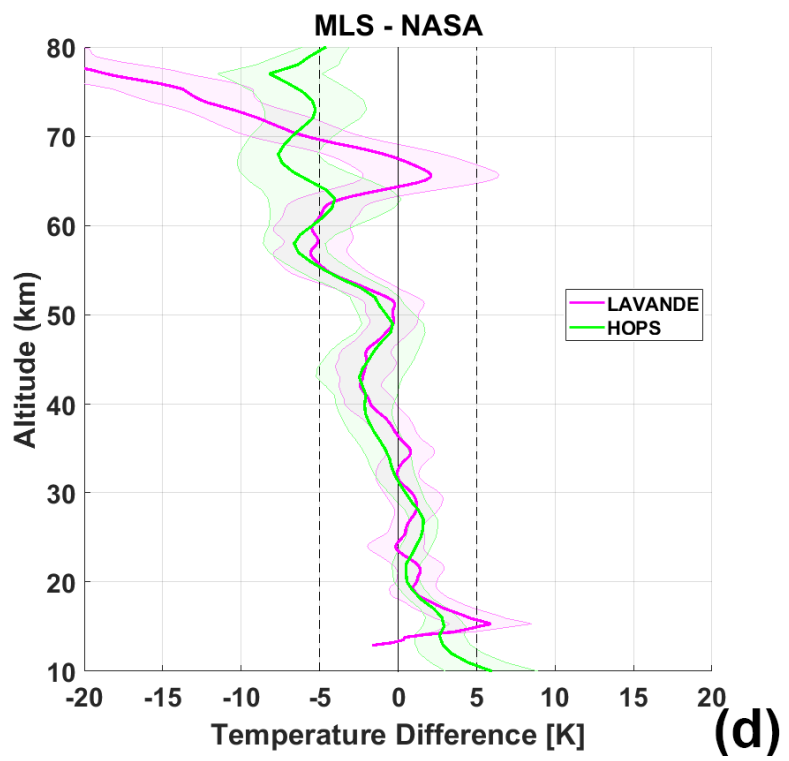

Figure 18. Cross-comparison of LAVANDE and HOPS ozone measurements for the $\mathrm{LiO}_{3} \mathrm{~S}, \mathrm{HOH}$, and HOHO NDACC lidars, MLS and SABER satellites, and Brewer-Mast and ECC ozonesondes, with respect to the NASA-STROZ lidar.

which increases almost linearly to a slight (but not significant) warm bias near $80 \mathrm{~km}$.

Panel (d) shows the average temperature differences between the NASA lidar and MLS during LAVANDE (magenta) and HOPS (green). Again, the slope of the temperature difference curves is consistent between both campaigns. There is a slight NASA cold bias near $15 \mathrm{~km}$ which increases to a slight NASA warm bias near $70 \mathrm{~km}$. The large, coherent, oscillating structures present at 50 and $60 \mathrm{~km}$ are known to result from errors in MLS geopotential (Wing et al., 2018b).

In the introduction, we gave the NDACC standard for ozone lidars as having an accuracy better than $\pm 3 \%$ between 12 and $35 \mathrm{~km}$ and an accuracy of better than $\pm 10 \%$ between
35 and $40 \mathrm{~km}$. The accuracy for NDACC temperature lidars was given as agreement better than $\pm 1 \mathrm{~K}$. Table 1 displays a summary of where each of the NDACC lidars is statistically equal at the $2 \sigma$ (95\% confidence level) to NASA-STROZ at the given accuracy threshold.

\section{Conclusions}

The HOPS intercomparison campaign of the DWD lidars at the Hohenpeißenberg Meteorological Observatory with the travelling standard NDACC reference NASA-STROZ lidar has demonstrated the consistency of the $\mathrm{HOH}$ lidar measurements with respect to measurements made using the $\mathrm{HOHO}$ 

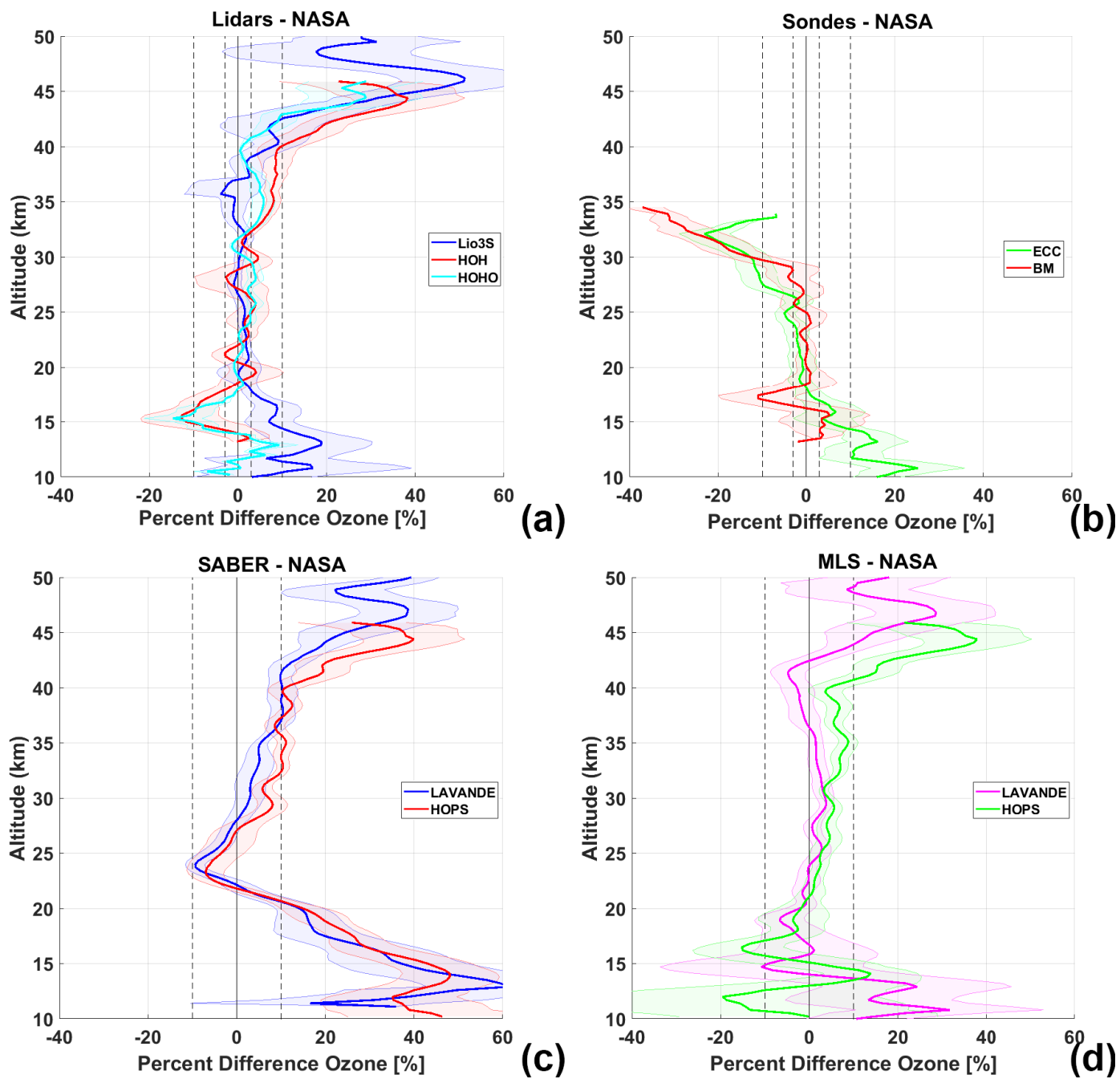

Figure 19. Cross-comparison of LAVANDE and HOPS temperature measurements for the $\mathrm{LiO}_{3} \mathrm{~S}$, LTA, HOH, and HOHO NDACC lidars, MLS and SABER satellites, and the radiosondes attached to the Brewer-Mast (RS92-SGP) and ECC (MeteoModem M10), with respect to the NASA-STROZ lidar.

lidar. We have confidence in the continued high quality of the Hohenpeißenberg dataset for both temperature and ozone after the installation of a new lidar system.

The intercomparison exercise has confirmed that the original DWD lidar, HOHO, continues to meet NDACC standards for ozone profiles at the $3 \%$ level between 16.5 and $43 \mathrm{~km}$ and at the $10 \%$ level between 10 and $44 \mathrm{~km}$. The HOHO lidar meets the NDACC temperature standards for accuracy at the $\pm 1 \mathrm{~K}$ level between 18 and $70 \mathrm{~km}$. The new DWD lidar, $\mathrm{HOH}$, meets the $3 \%$ ozone standard between 17 and $41 \mathrm{~km}$, the $10 \%$ ozone standard between 15 and $41 \mathrm{~km}$, and the $\pm 1 \mathrm{~K}$ temperature standard between 17 and $78 \mathrm{~km}$.

The cross-comparison of NDACC campaign at Hohenpeißenberg Meteorological Observatory (HOPS) and at Observatoire de Haute-Provence (LAVANDE) has allowed for the unique opportunity to assess potential biases in the NASA-STROZ reference lidar. When cross-compared against the $\mathrm{LiO}_{3} \mathrm{~S}$, LTA, and $\mathrm{HOH}$ lidar temperature profiles, and MLS and SABER satellite temperature profiles, the NASA-STROZ lidar appears to have a warm bias above $60 \mathrm{~km}$. The NASA temperatures have an apparent cold bias below $30 \mathrm{~km}$ when cross-compared to all other instruments. These possible biases may arise from algorithm initialisation choices and serve as strong motivation for another NDACC temperature algorithm paper.

When the ozone density profiles are cross-compared for both HOPS and LAVANDE instruments, there is a high degree of variability in all of the stratospheric lidars below $20 \mathrm{~km}$. The NASA lidar measures higher ozone densities than the DWD lidars but lower densities than the OHP lidar. At altitudes above $40 \mathrm{~km}$, the NASA lidar and OMPS-LP UV measure lower ozone density than $\mathrm{LiO}_{3} \mathrm{~S}, \mathrm{HOH}, \mathrm{HOHO}$, MLS, and SABER. 
Data availability. The data that support the findings of this study are openly available.

1. The data used in this publication were obtained from Hohenpeißenberg Meteorological Observatory as part of the Network for the Detection of Atmospheric Composition Change (NDACC) and are publicly available (ftp://ftp.cpc.ncep.noaa. gov/ndacc/station/hohenpei/, last access: 15 March 2020).

2. Local radiosoundings from Munich are available at http://weather.uwyo.edu/upperair/sounding.html (last access: 15 March 2020, Oolman, 2021).

3. MLS temperature and ozone profiles are available at https://doi.org/10.5067/Aura/MLS/DATA2520 (Schwartz et al., 2020).

4. SABER temperature and ozone profiles are available at ftp:// saber.gats-inc.com/ (last access: 15 March 2020, SABER Gats Inc., 2020).

5. The OMPS LP version 2.5 ozone profiles are available at https://doi.org/10.5067/X1Q9VA07QDS7 (Deland, 2017).

Author contributions. TJM, JTS, GS, and WS conducted the measurement campaign at Hohenpeißenberg. SGB conducted the blind comparison of all HOPS data. RW drafted the article. TJM, JTS, and WS provided access to the data and instruments. SK processed the OMPS data. All authors discussed the results and contributed to the final paper.

Competing interests. The authors declare that they have no conflict of interest.

Acknowledgements. This work is supported by the Deutscher Wetterdienst (DWD), the Institut National des Sciences de l'Univers/Centre National de la Recherche Scientifique (INSU/CNRS), and the NASA Upper Atmospheric Research Program.

Financial support. This research has been supported by the Deutscher Wetterdienst (DWD; GVPL-FEHPC).

Review statement. This paper was edited by Karin Kreher and reviewed by two anonymous referees.

\section{References}

Braathen, G. O., Godin-Beekmann, S., Keckhut, P., McGee, T. J., Gross, M. R., Vialle, C., and Hauchecorne, A.: Intercomparison of stratospheric ozone and temperature measurements at the $\mathrm{Ob}-$ servatoire de Haute Provence during the OTOIC NDSC validation campaign from 1-18 July 1997, Atmos. Chem. Phys. Discuss., 4, 5303-5344, https://doi.org/10.5194/acpd-4-5303-2004, 2004.
Claude, H., Schönenborn, F., Steinbrecht, W., and Vandersee, W.: New evidence for ozone depletion in the upper stratosphere, Geophys. Res. Lett., 21, 2409-2412, 1994.

De Mazière, M., Thompson, A. M., Kurylo, M. J., Wild, J. D., Bernhard, G., Blumenstock, T., Braathen, G. O., Hannigan, J. W., Lambert, J.-C., Leblanc, T., McGee, T. J., Nedoluha, G., Petropavlovskikh, I., Seckmeyer, G., Simon, P. C., Steinbrecht, W., and Strahan, S. E.: The Network for the Detection of Atmospheric Composition Change (NDACC): history, status and perspectives, Atmos. Chem. Phys., 18, 4935-4964, https://doi.org/10.5194/acp-18-4935-2018, 2018.

Deland, M.: OMPS-NPP L2 LP Ozone (O3) Vertical Profile swath daily 3slit V2.5, Greenbelt, MD, USA, Goddard Earth Sciences Data and Information Services Center (GES DISC) [data set], https://doi.org/10.5067/X1Q9VA07QDS7, 2017.

Flynn, L. E., Seftor, C. J., Larsen, J. C., and Xu, P.: The Ozone Mapping and Profiler Suite, in: Earth Science Satellite Remote Sensing, edited by: Qu, J. J., Gao, W., Kafatos, M., Murphy, R. E., and Salomonson, V. V., Springer, Berlin, Heidelberg. https://doi.org/10.1007/978-3-540-37293-6_15, 2006.

Flynn, L., Long, C., Wu, X., Evans, R., Beck, C. T., Petropavlovskikh, I., McConville, G., Yu, W., Zhang, Z., Niu, J., Beach, E., Hao, Y., Pan, C., Sen, B., Novicki, M., Zhou, S., and Seftor, C.: Performance of the Ozone Mapping and Profiler Suite (OMPS) products, J. Geophys. Res.-Atmos., 119, 61816195, https://doi.org/10.1002/2013JD020467, 2014.

Geh, B.: Aufbau einer automatischen Apparatur zur Messung der stratosphärischen Ozonkonzentration, $\mathrm{PhD}$ thesis, Diploma thesis, Ludwig-Maximilians Universität, Munich, Germany, 66 pp., 1987.

Godin, S., Carswell, A., Donovan, L., Claude, H., Steinbrecht, W., Mc Dermid, I., Mc Gee, T., Gross, M., Nakane, H., Swart, D., Bergwerff, H., Uchino, O., Gathen, P., and Neuber, R.: Ozone differential absorption lidar algorithm intercomparison, Appl. Optics, 38, 6225-6236, https://doi.org/10.1364/AO.38.006225, 1999.

Google Earth Pro, M.: Meteorological Observatory Hohenpeißenberg Kernel Description, available at: https://www.google. fr/maps/place/Deutscher+Wetterdienst+Meteorologisches+ Observatorium/@47.8014781,11.0095483,15, last access: 10 November 2020.

Hauchecorne, A. and Chanin, M.-L.: Density and temperature profiles obtained by lidar between 35 and $70 \mathrm{~km}$, Geophys. Res. Lett., 7, 565-568, https://doi.org/10.1029/GL007i008p00565, 1980.

Keckhut, P., McDermid, S., Swart, D., McGee, T., GodinBeekmann, S., Adriani, A., Barnes, J., Baray, J.-L., Bencherif, H., Claude, H., di Sarra, A. G., Fiocco, G., Hansen, G., Hauchecorne, A., Leblanc, T., Lee, Ch., Pal, S., Megie, G., Nakane, H., Neuber, R., Steinbrecht, W., and Thayer, J.: Review of ozone and temperature lidar validations performed within the framework of the Network for the Detection of Stratospheric Change, J. Environ. Monitor., 6, 721-733, 2004.

Kramarova, N. A., Bhartia, P. K., Jaross, G., Moy, L., Xu, P., Chen, Z., DeLand, M., Froidevaux, L., Livesey, N., Degenstein, D., Bourassa, A., Walker, K. A., and Sheese, P.: Validation of ozone profile retrievals derived from the OMPS LP version 2.5 algorithm against correlative satellite measurements, At- 
mos. Meas. Tech., 11, 2837-2861, https://doi.org/10.5194/amt11-2837-2018, 2018.

Kurylo, M. J., Thompson, A. M., and De Mazière, M.: The Network for the Detection of Atmospheric Composition Change: 25 Years Old and Going Strong, The Earth Observer, 28, 4-15, available at: https://eospso.gsfc.nasa.gov/earthobserver/sep-oct-2016 (last access: 12 September 2020), 2016.

Leblanc, T., Walsh, T. D., McDermid, I. S., Toon, G. C., Blavier, J.-F., Haines, B., Read, W. G., Herman, B., Fetzer, E., Sander, S., Pongetti, T., Whiteman, D. N., McGee, T. G., Twigg, L., Sumnicht, G., Venable, D., Calhoun, M., Dirisu, A., Hurst, D., Jordan, A., Hall, E., Miloshevich, L., Vömel, H., Straub, C., Kampfer, N., Nedoluha, G. E., Gomez, R. M., Holub, K., Gutman, S., Braun, J., Vanhove, T., Stiller, G., and Hauchecorne, A.: Measurements of Humidity in the Atmosphere and Validation Experiments (MOHAVE)-2009: overview of campaign operations and results, Atmos. Meas. Tech., 4, 2579-2605, https://doi.org/10.5194/amt4-2579-2011, 2011.

Leblanc, T., Sica, R. J., van Gijsel, J. A. E., Godin-Beekmann, S., Haefele, A., Trickl, T., Payen, G., and Gabarrot, F.: Proposed standardized definitions for vertical resolution and uncertainty in the NDACC lidar ozone and temperature algorithms Part 1: Vertical resolution, Atmos. Meas. Tech., 9, 4029-4049, https://doi.org/10.5194/amt-9-4029-2016, 2016a.

Leblanc, T., Sica, R. J., van Gijsel, J. A. E., Godin-Beekmann, S., Haefele, A., Trickl, T., Payen, G., and Liberti, G.: Proposed standardized definitions for vertical resolution and uncertainty in the NDACC lidar ozone and temperature algorithms - Part 2: Ozone DIAL uncertainty budget, Atmos. Meas. Tech., 9, 4051-4078, https://doi.org/10.5194/amt-9-4051-2016, 2016b.

Leblanc, T., Sica, R. J., van Gijsel, J. A. E., Haefele, A., Payen, G., and Liberti, G.: Proposed standardized definitions for vertical resolution and uncertainty in the NDACC lidar ozone and temperature algorithms - Part 3: Temperature uncertainty budget, Atmos. Meas. Tech., 9, 4079-4101, https://doi.org/10.5194/amt9-4079-2016, 2016c.

Loughman, R. P., Flittner, D. E., Herman, B. M., Bhartia, P. K., Hilsenrath, E., and McPeters, R. D.: Description and sensitivity analysis of a limb scattering ozone retrieval algorithm, J. Geophys. Res., 110, D19301, https://doi.org/10.1029/2004JD005429, 2005.

Margitan, J. J., Barnes, R. A., Brothers, G. B., Butler, J., Burris, J., Connor, B. J., Ferrare, R. A., Kerr, J. B., Komhyr, W. D., McCormick, M. P., McDermid, I. S., McElroy, C. T., McGee, T. J., Miller, A. J., Owens, M., Parrish, A. D., Parsons, C. L., Torres, A. L., Tsou, J. J., Walsh, T. D., and Whiteman, D.: Stratospheric ozone intercomparison campaign (STOIC) 1989: Overview, J. Geophys. Res., 100, 9193-9207, 1995.

McDermid, I., Bergwerff, J., Bodeker, G., Boyd, I., Brinksma, E., Connor, B., Farmer, R., Gross, M., Kimvilakani, P., Matthews, W., McGee, T., Ormel, F., Parrish, A., Singh, U., Swart, D., and Tsou, J.: OPAL: Network for the detection of stratospheric change ozone profiler assessment at Lauder, New Zealand 2. Intercomparison of revised results, J. Geophys. Res., 103, 2869328699, https://doi.org/10.1029/98JD02707, 1998.

McGee, T., Ferrare, R., Whiteman, D., Butler, J., Burris, J., and Owens, M.: Lidar measurements of stratospheric ozone during the STOIC campaign, J. Geophys. Res., 100, 9255-9262, https://doi.org/10.1029/94JD02390, 1995.
McGee, T. J., Whiteman, D. N., Ferrare, R. A., Butler, J. J., and Burris, J. F.: STROZ LITE: stratospheric ozone lidar trailer experiment, Opt. Eng., 30, 31-40, 1991.

Mertens, C. J., Mlynczak, M. G., López-Puertas, M., Wintersteiner, P. P., Picard, R. H., Winick, J. R., Gordley, L. L., and Russell, J. M.: Retrieval of mesospheric and lower thermospheric kinetic temperature from measurements of $\mathrm{CO}_{2} 15 \mu \mathrm{m}$ Earth Limb Emission under non-LTE conditions, Geophys. Res. Lett., 28, 1391-1394, https://doi.org/10.1029/2000GL012189, 2001.

Oolman, L.: The University of Wyoming Dept. of Atmospheric Science Radiosonde Repository, available at: http://weather.uwyo. edu/upperair/sounding.html, last access: 15 March 2021.

Pelon, J. and Megie, G.: Ozone monitoring in the troposphere and lower stratosphere: evaluation and operation of a ground-based lidar station, J. Geophys. Res., 87, 4947-4955, https://doi.org/10.1029/JC087iC07p04947, 1982.

Remsberg, E. E., Marshall, B. T., Garcia-Comas, M., Krueger, D., Lingenfelser, G. S., Martin-Torres, J., Mlynczak, M. G., Russell III, J. M., Smith, A. K., Zhao, Y., Brown, C., Gordley, L. L., Lopez-Gonzalez, M. J., Lopez-Puertas, M., She, C.-Y., Taylor, M. J., and Thompson, R. E.: Assessment of the quality of the Version 1.07 temperature-versus-pressure profiles of the middle atmosphere from TIMED/SABER, J. Geophys. Res., 113, D17101, https://doi.org/10.1029/2008JD010013, 2008.

Rezac, L., Jian, Y., Yue, J., Russell, J., Kutepov, A., Garcia, R., Walker, K., and Bernath, P.: Validation of the global distribution of $\mathrm{CO}$ volume mixing ratio in the mesosphere and lower thermosphere from SABER, J. Geophys. Res., 120, 12067-12081, https://doi.org/10.1002/2015JD023955, 2015a.

Rezac, L., Kutepov, A., Russell, J., Feofilov, A., Yue, J., and Goldberg, R.: Simultaneous retrieval of $T(p)$ and $\mathrm{CO}_{2}$ VMR from two-channel non-LTE limb radiances and application to daytime SABER/TIMED measurements, J. Atmos. Sol.-Terr. Phys., 130131, 23-42, https://doi.org/10.1016/j.jastp.2015.05.004, 2015b.

Rong, P. P., Russell III, J. M., Mlynczak, M. G., Remsberg, E. E., Marshall, B. T., Gordley, L. L., and López-Puertas, M.: Validation of Thermosphere Ionosphere Mesosphere Energetics and Dynamics/Sounding of the Atmosphere using Broadband Emission Radiometry (TIMED/SABER) v1.07 ozone at $9.6 \mu \mathrm{m}$ in altitude range $15-70 \mathrm{~km}$, J. Geophys. Res., 114, D04306, https://doi.org/10.1029/2008JD010073, 2009.

SABER Gats Inc.: Version 2.0 Temperatures, available at: ftp: //saber.gats-inc.com/, last access: 15 March 2020.

Schwartz, M., Livesey, N., and Read, W.: MLS/Aura Level 2 Temperature V005, Greenbelt, MD, USA, Goddard Earth Sciences Data and Information Services Center (GES DISC) [data set], https://doi.org/10.5067/Aura/MLS/DATA2520, 2020.

Schwartz, M. J., Lambert, A., Manney, G. L., Read, W. G., Livesey, N. J., Froidevaux, L., Ao, C. O., Bernath, P. F., Boone, C. D., Cofield, R. E., Daffer, W. H., Drouin, B. J., Fetzer, E. J., Fuller, R. A., Jarnot, R. F., Jiang, J. H., Jiang, Y. B., Knosp, B. W., Krüger, K., Li, J.-L. F., Mlynczak, M. G., Pawson, S., Russell III, J. M., Santee, M. L., Snyder, W. V., Stek, P. C., Thurstans, R. P., Tompkins, A. M., Wagner, P. A., Walker, K. A., Waters, J. W., and Wu, D. L.: Validation of the Aura Microwave Limb Sounder temperature and geopotential height measurements, J. Geophys. Res., 113, D15S11, https://doi.org/10.1029/2007JD008783, 2008. 
Smit, H. G. and Kley, D.: JOSIE: The 1996 WMO International intercomparison of ozonesondes under quasi flight conditions in the environmental simulation chamber at Jülich, in: Proceedings of the XVIII Quadrennial Ozone Symposium, Jülich, Germany, 971-974, 1998.

Steinbrecht, W., Winkler, P., and Claude, H.: Ozon-und Temperaturmessungen mittels Lidar am Hohenpeißenberg, Rep. No. 200, Deutscher Wetterdienst, Offenbach, Germany, 1997.

Steinbrecht, W., Neuber, R., von der Gathen, P., Wahl, P., McGee, T., Gross, M., Klein, U., and Langer, J.: Results of the 1998 NyÅlesund Ozone Monitoring Intercomparison, J. Geophys. Res., 104, 30515-30523, 1999.

Steinbrecht, W., McGee, T. J., Twigg, L. W., Claude, H., Schönenborn, F., Sumnicht, G. K., and Silbert, D.: Intercomparison of stratospheric ozone and temperature profiles during the October 2005 Hohenpeißenberg Ozone Profiling Experiment (HOPE), Atmos. Meas. Tech., 2, 125-145, https://doi.org/10.5194/amt-2125-2009, 2009.

Stübi, R., Levrat, G., Hoegger, B., Viatte, P., Staehelin, J., and Schmidlin, F. J.: In-flight comparison of Brewer-Mast and electrochemical concentration cell ozonesondes, J. Geophys. Res., 113, D13302, https://doi.org/10.1029/2007JD009091, 2008.

Tarasick, D. W., Davies, J., Smit, H. G. J., and Oltmans, S. J.: A re-evaluated Canadian ozonesonde record: measurements of the vertical distribution of ozone over Canada from 1966 to 2013, Atmos. Meas. Tech., 9, 195-214, https://doi.org/10.5194/amt-9195-2016, 2016.

Waters, J. W., Froidevaux, L., Harwood, R. S., Jarnot, R. F., Pickett, H. M., Read, W. G., Siegel, P. H., Cofield, R. E., Filipiak, M. J., Flower, D. A., Holden, J. R., Lau, G. K., Livesey, N. J., Manney, G. L., Pumphrey, H. C., Santee, M. L., Wu, D. L., Cuddy, D. T., Lay, R. R., Loo, M. S., Perun, V. S., Schwartz, M. J., Stek, P. C., Thurstans, R. P., Boyles, M. A., Chandra, K. M., Chavez, M. C., Chen, G.-S., Chudasama, B. V., Dodge, R., Fuller, R. A., Girard, M. A., Jiang, J. H., Jiang, Y., Knosp, B. W., LaBelle, R. C., Lam, J. C., Lee, K. A., Miller, D., Oswald, J. E., Patel, N. C., Pukala, D. M., Quintero, O., Scaff, D. M., Snyder, W. V., Tope, M. C., Wagner, P. A., and Walch, M. J.: The Earth observing system microwave limb sounder (EOS MLS) on the aura Satellite, IEEE T. Geosci. Remote, 44, 1075-1092, https://doi.org/10.1109/TGRS.2006.873771, 2006.
Wing, R., Hauchecorne, A., Keckhut, P., Godin-Beekmann, S., Khaykin, S., McCullough, E. M., Mariscal, J.-F., and d'Almeida, É.: Lidar temperature series in the middle atmosphere as a reference data set - Part 1: Improved retrievals and a 20year cross-validation of two co-located French lidars, Atmos. Meas. Tech., 11, 5531-5547, https://doi.org/10.5194/amt-115531-2018, 2018.

Wing, R., Hauchecorne, A., Keckhut, P., Godin-Beekmann, S., Khaykin, S., and McCullough, E. M.: Lidar temperature series in the middle atmosphere as a reference data set - Part 2: Assessment of temperature observations from MLS/Aura and SABER/TIMED satellites, Atmos. Meas. Tech., 11, 6703-6717, https://doi.org/10.5194/amt-11-6703-2018, 2018 b.

Wing, R., Steinbrecht, W., Godin-Beekmann, S., McGee, T. J., Sullivan, J. T., Sumnicht, G., Ancellet, G., Hauchecorne, A., Khaykin, S., and Keckhut, P.: Intercomparison and evaluation of ground- and satellite-based stratospheric ozone and temperature profiles above Observatoire de Haute-Provence during the Lidar Validation NDACC Experiment (LAVANDE), Atmos. Meas. Tech., 13, 5621-5642, https://doi.org/10.5194/amt13-5621-2020, 2020.

Zawada, D. J., Rieger, L. A., Bourassa, A. E., and Degenstein, D. A.: Tomographic retrievals of ozone with the OMPS Limb Profiler: algorithm description and preliminary results, Atmos. Meas. Tech., 11, 2375-2393, https://doi.org/10.5194/amt-112375-2018, 2018. 